NBER WORKING PAPER SERIES

\title{
WHICH IMMIGRANTS ARE MOST INNOVATIVE AND ENTREPRENEURIAL? DISTINCTIONS BY ENTRY VISA
}

\author{
Jennifer Hunt \\ Working Paper 14920 \\ http://www.nber.org/papers/w14920

\begin{abstract}
NATIONAL BUREAU OF ECONOMIC RESEARCH
1050 Massachusetts Avenue

Cambridge, MA 02138
\end{abstract} \\ April 2009
}

I am grateful to David Munroe and Marjolaine Gauthier-Loiselle for research assistance, to David Green, Bill Kerr, Lindsay Lowell, participants in workshops at McGill and UBC, and friends in science and engineering for comments. I thank the Social Science and Humanities Research Council of Canada for financial support. This paper was written while I was a visiting professor at the University of British Columbia. I am also affiliated with the CEPR, the IZA and the DIW--Berlin. The views expressed herein are those of the author(s) and do not necessarily reflect the views of the National Bureau of Economic Research.

NBER working papers are circulated for discussion and comment purposes. They have not been peerreviewed or been subject to the review by the NBER Board of Directors that accompanies official NBER publications.

(C) 2009 by Jennifer Hunt. All rights reserved. Short sections of text, not to exceed two paragraphs, may be quoted without explicit permission provided that full credit, including $\odot$ notice, is given to the source. 
Which Immigrants Are Most Innovative and Entrepreneurial? Distinctions by Entry Visa Jennifer Hunt

NBER Working Paper No. 14920

April 2009

JEL No. J61,O31

\begin{abstract}
$\underline{\text { ABSTRACT }}$
Using the 2003 National Survey of College Graduates, I examine how immigrants perform relative to natives in activities likely to increase U.S. productivity, according to the type of visa on which they first entered the United States. Immigrants who first entered on a student/trainee visa or a temporary work visa have a large advantage over natives in wages, patenting, commercializing or licensing patents, and publishing. In general, this advantage is explained by immigrants' higher education and field of study, but this is not the case for publishing, and immigrants are more likely to start companies than natives with similar education. Immigrants without U.S. education and who arrived at older ages suffer a wage handicap, which offsets savings to the United States from their having completed more education abroad. Immigrants who entered with legal permanent residence do not outperform natives for any of the outcomes considered.
\end{abstract}

Jennifer Hunt

Professor of Economics

Department of Economics

McGill University

Leacock Building Room 443

855 Sherbrooke Street West

Montreal, QC, H3A 2T7

Canada

and NBER

jennifer.hunt@mcgill.ca 


\section{Introduction}

There has been considerable public debate over skilled immigration to the United States in recent years, much of it on the merits or otherwise of the $\mathrm{H}-1 \mathrm{~B}$ visa program for specialty workers and the level of the annual cap on such visas. Hira (2007), Matloff (2008), Miano (2007), Senator Chuck Grassley R-Iowa ${ }^{1}$ and others call for a cut in the $\mathrm{H}-1 \mathrm{~B}$ cap, arguing that $\mathrm{H}-1 \mathrm{~B}$ workers are not particularly skilled, undercut native wages, and reduce native employment both directly and by facilitating off-shoring. Critics of the $\mathrm{H}-1 \mathrm{~B}$ also have unfavorable views of the intra-company transferee $\mathrm{L}$ visa, while Borjas (2002) argues that the foreign student program is detrimental to the United States. By constrast, Kirkegaard (2007), employers (Microsoft ${ }^{2}$, U.S. Chamber of Commerce ${ }^{3}$ ) and others advocate an increase in the $\mathrm{H}-1 \mathrm{~B}$ cap and in skilled immigration more generally to enable firms to compete in global markets. Along with the Institute for Electrical and Electronics Engineers (2007), employers call for faster transitions from temporary visas, including student visas, to legal permanent residence.

The various parties disagree in part because they have different objective functions. However, they also disagree on certain factual matters that have yet to be fully investigated. For example, economists have an as yet incomplete picture of the aggregate benefits to natives of skilled immigration. In this paper, I address this by providing evidence not merely on skilled immigrants' private productivity, as measured by their wage, but also on their success in creating, disseminating and commercializing knowledge, activities with public benefits likely to increase U.S. total factor productivity. Specifically, I examine patenting, commercializing and licensing patents, publishing books and papers and writing papers for presentation at major conferences, and starting successful companies. I use patents to proxy for inventions, a type of knowledge with the potential to increase total factor productivity. While in the short run the purpose of a patent is to

\footnotetext{
${ }^{1}$ grassley.senate.gov/news/Article.cfm?customel_dataPageID_1502=10956, accessed 8 February 2009.

${ }^{2}$ www.microsoft.com/Presspass/exec/billg/speeches/2007/03-07Senate.mspx, accessed 9 February 2009.

${ }^{3}$ www.uschamber.com/international/agenda/immigration_policies.htm, accessed 9 February 2009.
} 
keep the benefit of an invention private, once the patent expires or is licensed, the invention may be used by other firms to increase their productivity. Patenting may also be correlated with innovations embodied in tacit knowledge and disseminated by inter-firm worker mobility. I use the publication and presentation of books and papers to measure dissemination of knowledge created both academically and commercially. Since knowledge must be commercialized in order to increase total factor productivity, I seek evidence of the commercialization of knowledge in the commercialization and licensing of patents, and in the founding of successful companies.

I distinguish among skilled immigrants according whether they first came to the United States as a legal permanent resident, on a temporary work visa, on a student/trainee visa, or as a dependent of a temporary visa holder, and I further distinguish types of student/trainee. This makes the results directly informative to policy-makers, who can use them to influence their decisions about which visa classes to expand or shrink and which transitions to legal permanent residence to facilitate. However, I do not undertake a full cost-benefit analysis of skilled immigration's impact, as I do not capture all possible benefits of skilled immigration and I ignore potential negative effects. Borjas (2006b), for example, calculates that immigrants with PhDs depress the wages of native PhDs.

To the extent that the activities I study have a public good component, skilled immigrants might contribute to native welfare simply by increasing the size of the population likely to engage in them. However, immigrants might outperform natives if a combination of self-selection and the visa system leads immigrants to be inherently more creative, inventive or entrepreneurial. Alternatively, immigrants may have similar (or lesser) natural abilities, but be more concentrated in the highest education groups, or more specialized in areas in which knowledge creation, dissemination and commercialization occurs. One of the aims of the paper is to discriminate between these possibilities.

While it may appear obvious that U.S. total factor productivity benefits from the presence of creative, inventive and entrepreneurial immigrants in the United States, certain conditions must hold for this to be true. It must be the case that immigrants would have been less innovative abroad, or would not have been able to commercialize their 
innovation as effectively abroad, or that innovation and its dissemination and commercialization abroad benefit Americans less than when these occur in the United States. Kahn and MacGarvie (2008) provide evidence for the first condition, Eaton and Kortum (1999) for the third. It must also be the case that there is little crowd-out of native innovation, or that crowd-out has little effect on native contributions to productivity, due to increased task specialization and use of comparative advantage. There is some empirical evidence on this issue. Hunt and Gauthier-Loiselle (2009) provide evidence that skilled immigrants have positive rather than negative spill-overs on inventors, while Borjas (2006a) does not find that immigration deters natives as a whole from attending graduate school. Peri and Sparber (2008) show that skilled natives react to immigration by entering occupations with more communicative and interactive skill requirements, in line with their comparative advantage.

My work is not the first to assess the performance of skilled immigrants to the United States. Peri (2007) notes immigrants are over-represented among recent U.S.--based Nobel Prize winners; Anderson and Platzer (2006) show immigrants represent 25\% of founders of recent public venture-backed U.S. companies; Wadhwa, Saxenian et al. (2007) show immigrants founded of $25 \%$ of new high-tech companies with more than one million dollars in sales in 2006; and Stephan and Levin (2001) show immigrants are over-represented among members of the National Academy of Sciences and the National Academy of Engineering, among authors of highly-cited science and engineering journal articles, and among founders of bio-tech companies undergoing IPOs. Kerr (2007) documents the surge in the share of U.S. patents awarded to U.S.-based inventors with Chinese and Indian names to $12 \%$ of the total by 2004, and Wadhwa, Jasso et al. (2007) find that non-U.S. citizens account for $24 \%$ of international patent applications from the United States.

My work differs in its use of a representative sample of college graduates allowing various outcomes to be considered together and containing covariates permitting an explanation of why immigrants perform well. Furthermore, my comparison of immigrant outcomes by visa class is unique as far as the non-wage outcomes are concerned. I build 
on the results of Hunt and Gauthier-Loiselle (2009), who show that college-educated immigrants are twice as likely to patent as college-educated natives, due to their concentration in science and engineering. I am motivated by considerations similar to those of Paserman (2008), who does not find that skilled immigration to Israel raised manufacturing productivity. I follow two papers in linking patenting and visa type: Kerr and Lincoln (2008), who tie increases in $\mathrm{H}-1 \mathrm{~B}$ visas to increased patenting by inventors with Indian and Chinese names in cities with high $\mathrm{H}-1 \mathrm{~B}$ visa applications; and Stuen, Mobarak and Maskus (2007), who find that immigrant students increase U.S. university patenting and science and engineering publishing. ${ }^{4}$ I complement the work of Fairlie (2008), who examines the determinants of start-ups, finding immigrants are more likely than natives to start a business with at least one employee, an advantage they retain even when compared to natives with similar characteristics.

My analysis of wages by visa type differs from that of some previous authors in its emphasis on the entry visa rather than the current visa. The wages of immigrants currently on temporary visas are likely to be lower than the immigrants' long-run productivity in the United States. Almost by definition, immigrants on temporary visas have not been in the United States for long, and are still in the process of assimilating to the U.S. labor market. Furthermore, the long-run contribution of immigrants is influenced by selective return migration: Lubotsky (2007) finds evidence that lower-paid immigrants disproportionately leave the United States. ${ }^{5}$ By including in my analysis former holders of temporary visas, I am able to assess the longer-run potential of those who enter on temporary visas and remain in the United States. The small number of existing papers on entry visa type do not always have a native comparison group. Using a sample of new legal permanent residents (the New Immigrant Survey Pilot) and always conditioning on worker characteristics, Massey and Nalone (2002) observe that the highest earners

\footnotetext{
${ }^{4}$ On immigration and patenting, see also Chellaraj, Maskus and Mattoo (2008), Morgan, Kruytbosch and Kannankutty (2003) and Peri (2007).

${ }^{5}$ Among the few concrete return migration statistics are those of Finn $(2000,2005)$, who shows that about half of foreign $\mathrm{PhD}$ recipients are still in the United States five years after graduating, with the share rising over the 1990s.
} 
initially arrived as temporary workers, while the next most highly paid group arrived as students. Using Canadian data on new permanent residents, Sweetman and Warman (2008) find that the highest earners are those adjusting status from temporary worker or student. In such samples of new immigrants, as the Sweetman and Warman results hint, the differences may principally reflect time since migration.

Using the nationally representative 2003 National Survey of College Graduates (NSCG), I find that immigrants who first entered the United States on a student/trainee visa or a temporary work visa have a large advantage over natives in wages, patenting, commercializing or licensing patents, and writing books or papers for publication and presentation at conferences. Those who arrived on work visas and members of every sub-category of the student/trainee group except one outperform natives on every measure. The most successful immigrants arrived as post-doctoral fellows and medical residents. Immigrants who arrived as legal permanent residents (principally through family unification) perform similarly to natives, while those who arrived as dependents of temporary visa holders or on other temporary visas perform worse than natives. I conclude that firms, universities and teaching hospitals are successful in attracting and selecting immigrants who remain in the United States to outperform natives, thereby likely increasing U.S. total factor productivity. By contrast, natives and immigrants already in the United States sponsor college-educated immigrant spouses and family members who perform similarly to college-educated natives.

For non-wage outcomes, much of the work and student/trainee visa immigrant advantage is explained by immigrants' higher education and field of study. U.S. firms, universities and teaching hospitals are thus identifying innovative immigrants based mainly on their educational qualities, rather than on superior innate creative or inventive abilities. However, even compared to similar natives, three of the four student/trainee groups retain an advantage in writing books or papers for publication or presentation. Furthermore, conditional on education, immigrants are more likely than natives to start a company with more than ten workers, suggesting that immigrants have a niche in start-ups based on technical knowledge from master's and doctoral degrees. Also, although immigrants 
who arrived as college students perform similarly on all outcomes to similarly educated natives, universities do identify immigrant college students who, if they remain in the United States, eventually obtain more education than native college students. Compared to similar natives, immigrants who entered as legal permanent residents perform worse on all outcomes except company start-ups.

For wages, taking immigrants' higher education and more lucrative field of study into account does more than explain the immigrant advantage: each entry visa group earns less than similar natives, except immigrants who arrived as college students and those who arrived on temporary work visas, who earn the same. However, if all immigrants had arrived in the United States as children, and had acquired U.S. education, each immigrant group would earn the same as or more than similar natives. This suggests that the unobserved general ability of immigrants is similar to or greater than that of natives, but that immigrants are handicapped by weaker language and culture-specific skills. ${ }^{6}$ Immigrants who arrived on work visas, as post-doctoral fellows and medical residents, and as graduate students suffer most from having arrived in the United States at an older age, and, in the case of the first two groups, with a foreign highest degree. Therefore, while these groups might appear appealing to the United States because of the free education they bring with them, this education does come at a price for the United States. Holding a foreign highest degree has no impact on patenting and authoring books or papers, and age at arrival has a weaker influence on these outcomes than on wages.

In order to relate my work to the literature on the performance of workers holding H-1B visas, I also examine outcomes by current visa status: Matloff (2008) and Miano (2007) find that $\mathrm{H}-1 \mathrm{~B}$ holders earn less than similar natives, while Mithas and Lucas (2008) find they earn more. I confirm the finding of Lowell and Avato (2007), who study science and engineering occupations in the 2003 NSCG, that it is crucial to distinguish

\footnotetext{
${ }^{6}$ Previous papers have shown that age at arrival has a negative effect on wages e.g. Borjas (1995). Bleakley and Chin (2004) show the importance of language acquisition, though Schaafsma and Sweetman (2001) show that much of the effect in Canada reflects zero returns to foreign experience and lower returns to foreign than Canadian education.
} 
between holders of temporary work visas for whom this was also their entry visa type and holders of temporary work visas whose entry visa was a student/trainee visa. While temporary work visa holders collectively earn less than similar natives, this is the net effect of a conditional wage advantage for the former group, and a larger conditional wage disadvantage for the latter group. The results underscore the insights gained from classifying immigrants by entry visa.

\section{Background on U.S. Visas}

Respondents in my data who were born abroad without U.S. citizenship are asked their visa status when they first came to the United States for six months or more. In this section, I describe the most common visas for skilled immigrants, which of the general categories on the survey they are likely to correspond to, which U.S.--based agents influence the selection of immigrants of each visa type, and how immigrants may remain in the United States.

The first option on the survey is "Permanent U.S. Resident Visa (Green Card)", which I shall henceforth refer to as a green card. This has an unambiguous mapping to legal permanent residence, but does not distinguish between types of green card, notably between employment-based and family-based green cards. ${ }^{7}$ One can characterize this group as having been selected by their relatives under family unification provisions, since most green cards are family-based, and recipients of family-based green cards are more likely to be new arrivals than recipients of employment-based green cards. ${ }^{8}$

The second survey option is "Temporary U.S. Resident Visa for temporary work (e.g., H-1B, L-1A, L-1B, etc.)". H-1B visas (prior to 1991, simply $\mathrm{H}-1$ visas) are for workers in specialty occupations, defined as requiring a body of specialized knowledge and a

\footnotetext{
${ }^{7}$ Information on different types of green card is available at travel.state.gov/visa/immigrants/types/types_1326.html, accessed 25 March 2009.

${ }^{8}$ See Massey and Nalone (2002). Most college-educated winners of the diversity lottery would also be in this category, but would be a small share of it.
} 
bachelor's degree or equivalent. $.^{9} \mathrm{~L}-1 \mathrm{~A}$ and $\mathrm{L}-1 \mathrm{~B}$ are visas for intra-company transferees: the holder must have worked for the company for a year abroad, and in most cases requires a bachelor's degree or equivalent. This second option would also include Canadian and Mexicans on TN visas, who must have a job offer in the United States from a list of occupations which in most cases require a bachelor's degree, and holders of $\mathrm{O}$ visas for workers of extraordinary ability. The $\mathrm{J}-1$ or exchange visitor visa, administered by the Department of State, is an eclectic visa whose holders span au pairs to professors to students. Some J-1 holders are likely to respond that they had a temporary work visa. This second survey category can be characterized as one whose members are chosen among the applicants by firms, within the government framework generally requiring applicants to have a bachelor's degree.

The third option is "Temporary U.S. Resident Visa for study or training (e.g., F-1, J-1, H-3, etc.)". Most students studying for a degree at a four-year college or university obtain F-1 visas, unless they have certain types of graduate fellowship, usually foreign-funded, in which case they hold $\mathrm{J}-1$ visas. Post-doctoral fellows and holders of foreign medical degrees doing a medical residency in the United States in general hold J-1 visas. There are also provisions for firms to engage trainees on $\mathrm{J}-1$ or $\mathrm{H}-3$ visas. A small number of foreign students studying at U.S. high schools hold F-1 visas, while some survey respondents may have initially entered the United States for vocational training on an M-1 visa before going on to obtain a bachelor's degree. Holders of the visas in this third category (except firm trainees) are chosen by universities and their teaching hospitals.

The fourth option is "Temporary U.S. Resident Visa as the dependent of another person (e.g., F-2, H-4, J-2, K-2, L-2, etc.)". These dependents are a mix of spouses and children of principal temporary visa holders (a $\mathrm{K}-2$ holder is the minor child of a $\mathrm{K}-1$ holder, who in turn is the fiancé(e) of a U.S. citizen). While spouses of J-1 and L visa holders may work, spouses of $\mathrm{H}-1$ and $\mathrm{F}-1$ visa holders may not. Holders of these visas are chosen by their spouses, or by genetics.

\footnotetext{
${ }^{9} \mathrm{~A}$ description of the current full set of temporary visas can be found by clicking on "non-immigrant visas" at travel.state.gov/visa/temp/temp_1305.html, accessed 25 March 2009.
} 
The final option is "Other Temporary U.S. Resident Visa". Given the myriad of possible visas, it is hard to judge what the most common type is likely to be in this category, though it would include E visa holders (treaty traders and investors).

In order to stay permanently in the United States, an immigrant must obtain legal permanent residence (unless he or she renews TN visas yearly forever). Holders of F1 student visas may not apply for employment-based green cards, but may apply for temporary work visas (and may work for a year as "practical training"). Holders of J-1 visas may in principle not apply for green cards, and are often bound to return to their home country. H-1B visas last three years and can be renewed once (prior to 1991, H-1 visas could be used for five years); the transition to an employer-sponsored green card has been officially sanctioned since 1991, as is the case for L visa holders. However, as of 2006, the number of pending applications for adjustment to employment-based green cards was nine times the annual quota available (Wadhwa, Jasso et al. 2007). Country of origin quotas mean that immigrants from different countries face different waiting times, with Indians and Chinese particularly facing longer waits in recent years. ${ }^{10}$ Those waiting for green cards are bound by the terms of their temporary visa, which include a prohibition on changing employers and on spousal employment for $\mathrm{H}-1 \mathrm{~B}$ holders, and on starting a company for all temporary visa holders except treaty investors and L-1 visa holders setting up a subsidiary. However, many skilled immigrants on temporary visas, including student visas, obtain permanent residence through their marriage to a U.S. citizen, as numerically unlimited green cards for spouses of U.S. citizens are much faster and easier to obtain than employment-based green cards. ${ }^{11}$

\footnotetext{
${ }^{10}$ See the Visa Bulletins at travel.state.gov/visa/frvi/bulletin/bulletin_1770.html, accessed 25 March 2009.

${ }^{11}$ See Jasso, Rosenzweig and Smith (2000), who emphasize immigrant adaptability to changing visa options, and Wadhwa, Jasso et al. (2007).
} 


\section{$3 \quad$ Data and descriptive statistics}

I use the 2003 wave of the National Survey of College Graduates, data collected under the auspices of the National Science Foundation. The survey is a stratified random sample of respondents to the 2000 census long form who reported having a bachelor's degree or higher. The survey has the advantages of a large sample size, and information on patenting, publishing and starting companies; the field of study of the highest degree; the type of entry visa for immigrants (described in the previous section); immigrants' current visa; and whether each degree was received in the United States (which allows me to sub-divide the student/trainee entry visa category). Immigrants arriving between April 2000 and October 2003 are not in the sampling frame, and obversely, all immigrants in the data have been in the United States at least three years.

All respondents who have ever worked are asked a series of questions concerning the five-year window since October 1998: how many distinct papers they had (co-)authored for presentation at regional, national or international conferences; how many papers they had (co-)authored had been accepted for publication in refereed professional journals; how many books or monographs they had ( $\mathrm{CO}^{-}$)authored had been accepted for publication; how many U.S. patent applications they had made; how many U.S. patents had been granted; how many granted patents had resulted in commercialized products or processes or had been licensed.

Questions asked of all respondents currently working allow me to construct a dummy variable for whether the respondent had in the last five years founded a company that currently has more than ten employees. I would prefer to capture companies with at least one employee, but I must rely on the firm size variable whose smallest category is ten or fewer employees. I construct hourly wages from salary, weeks and hours on the principal job.

I use three samples in my analysis. The first contains all those who have ever worked, which is the group answering the publishing and patenting questions. The second contains those currently working, for the analysis of start-ups. The third contains those currently 
working who do not have implausible wage values, for the analysis of wages. I keep the latter two samples separate, as I do not wish to exclude observations with implausible wages from the start-up analysis, as company founders may be particularly likely to report odd salaries. I retain in all samples those indicating being self-employed on their principal job. I include in my samples respondents 64 or younger (the youngest respondent is 23, but few are younger than 26). The Data Appendix gives more details on the data and sample construction.

Table 1 shows how the three (weighted) samples are distributed by nativity and entry visa. The samples sizes range from 75,940 for the wage sample (column 1) to 90,293 for the patent and publication sample (columns 3 and 4 ). Column 3 shows that $1.1 \%$ of the latter sample are born outside the U.S. and its territories to American parents, with another $0.3 \%$ born in U.S. territories (principally Puerto Rico). Another $5.2 \%$ of the sample are immigrants who arrived with green cards, and this group represents $43 \%$ of immigrants (column 4). $12 \%$ of immigrants arrived on temporary work visas, $24 \%$ on student/trainee visas, $12 \%$ as dependents of temporary visa holders, and $9 \%$ on other temporary visas. For immigrants arriving in the United States after 1990, the share that arrived with a temporary work visa is much higher, at the expense of those who arrived with a green card (these results are not reported). This likely reflects longer spells in the United States for those arriving with a green card combined with a greater increase in temporary work visas than employment-based green cards after 1991, when the Immigration Act of 1990 came into effect.

I split the student/trainee visa group into those who came to the United States to do a bachelor's degree (after high school completion abroad), those who came to do a graduate degree of any kind (having obtained a bachelor's degree abroad), those who came after having completed either a doctorate or a professional degree abroad (post-doctoral research fellows or medical residents or fellows, see below), and a residual "other" group, whose members arrived either for pre-bachelor study or as firm trainees. The largest group of student/trainee visa entries are those who arrived in the United States for graduate school (column 3). 
Table 2 shows the means of the dependent variables I shall consider, by nativity and entry visa. The first two rows of panel A show that the immigrants have higher wages than natives, and are more likely to have started a firm, been granted a patent, commercialized or licensed a patent, and have authored any publication or paper for conference presentation (columns 1-5). These differences are all statistically significant except for the case of start-ups in column 2. The kernel density plot in Figure 1's upper left panel shows that immigrant and native wages are distributed very similarly, so I do not extend my wage analysis beyond mean regression. For patents and publications, the intensive margin may matter in addition to the extensive margin. Figure 1 suggests that this is particularly the case for of publications (lower right panel), so I also consider differences in the probability of frequent publishing. I choose six publications or papers as the threshold for frequent publishing as there is a sharp fall in the share of people with seven rather than five or six. ${ }^{12}$ Table 2 column 6 shows this outcome has the largest immigrant-native gap: the immigrant propensity is double the native propensity. ${ }^{13}$ Panel B of Table 2 shows the means of the outcomes by detailed entry visa (in the results section, I use graphs to display these means more clearly).

Writing books and papers is not primarily the pursuit of academics. Only 17\% of respondents with a publication or paper are employed at a four-year post-secondary institution (this share includes almost all currently enrolled full-time doctoral students, though a minority of currently enrolled master's students), and the share rises only modestly to $32 \%$ for respondents with more than six publications or papers. However, some respondents who authored their research before leaving academics are not captured in these shares.

Panel A of Table 3 shows that immigrants are much more likely than natives to have studied computer science/mathematics (an aggregate occupation dominated by computer science), physical science and especially engineering for their highest degree. A few num-

\footnotetext{
${ }^{12}$ Among those with any publications or papers, $6 \%$ have five, $6 \%$ six, and $2.7 \%$ seven.

${ }^{13} \mathrm{I}$ have also analyzed the probability of frequent patenting, but the results as very similar to those for the probability of any patent, so I do not present them.
} 
bers from the detailed entry visas in Panel B are worth highlighting. Those who arrived on work visas are particularly over-represented in computer science/mathematics (13.8\% studied this field, compared to $3.6 \%$ of natives) and engineering (21.9\%, compared to $5.3 \%$ of natives), as are those who arrived for college (9.8\% and 18.8\%) and graduate school (16.8\% and $25.1 \%$ ), with the latter group also particularly over-represented in physical sciences $(6.8 \%$, compared to $1.7 \%$ for natives). The post-doctoral group, on the other hand, is concentrated in biological science (24.2\% compared to $4.0 \%$ for natives), physical science (11.6\%) and in "science and engineering-related" fields (50.4\%). The latter aggregate field is dominated by health: these immigrants come to the United States for medical residencies or fellowships after a medical degree abroad.

In Table 4, I present the weighted means of the education and other variables. The first two rows of Panel A show that immigrants have more of every type of post-college degree than natives, with the gap especially large for doctoral degrees. ${ }^{14}$ Panel B shows that immigrants in every group except those who arrived on a green card and on "other" student/trainee visas have more education than natives, including those who arrived for college. ${ }^{15}$ The immigrants oldest on arrival in the United States are those who arrived on work visas and as post-docs (column 6), with an average age of 29.7. Column 7 shows the share of each entry visa group with a highest degree earned in the United States. Appendix Tables 1 and 2 give the means of other covariates by entry visa. I defer statistics by current visa until later in the paper.

\section{Method}

All my outcomes of interest except wages are binary outcomes, so for most regressions I estimate probits weighted with sample weights, presenting marginal effects:

$$
P\left(Y_{i}\right)=\beta_{0}+I_{i} \beta_{1}+X_{1 i} \beta_{2}+\epsilon_{i}
$$

\footnotetext{
${ }^{14}$ Foreign law and medical degrees are classified as professional degrees, even though they often require fewer years of study than in the United States, where a bachelor's degree must first be completed.

${ }^{15}$ Because the survey samples only college graduates, if universities accept many foreign college students who drop out, I will not observe it.
} 
where $i$ indexes individuals and $I_{i}$ is a vector containing dummies for all the entry visa groups, for those born abroad to American parents, and for those born in U.S. territories (I do not present the coefficients on the latter two dummies). Alternatively, immigrants are classified by current visa. The dependent variables are the innovation and startup outcomes in columns $2-6$ in Table 2 . The $X_{1 i}$ in whose influence I am particularly interested are field of study of highest degree (30 dummies), highest degree, whether the highest degree was earned in the United States and immigrant age at arrival in the United States, but I also consider age, foreign and U.S. potential experience, years since migration, arrival cohort effects, current enrollment status (three dummies), sex, race and, for the publications and papers outcome, employment status, employment at a four-year post-secondary institution and the interaction of education and field.

For wages, I estimate a weighted least squares equivalent with robust standard errors:

$$
\log w=\gamma_{0}+I_{i} \gamma_{1}+X_{2 i} \gamma_{2}+\eta_{i}
$$

and consider the covariates in $X_{1 i}$ from (1), along with tenure, self-employment status and census region of residence.

Since some entry visa categories themselves are closely linked to age at arrival, I need a smooth function of age at arrival to attempt to identify the effects separately, and I elect to use a spline with knots at ten yearly intervals beginning at age 0 , with a final knot at age 50. My specification allows me to identify separate effects for age at arrival, years since migration and arrival cohort (decade of arrival), but it is well-known that distinguishing such effects in a single cross-section is fraught with peril. As a check, I analyze annual salaries using the pooled 1993 and 2003 surveys (I do not report the results). The age at arrival effects that result are very similar to those estimated below for hourly wages in the 2003 cross-section, and, similarly to what I find below, have a much larger effect on the coefficients on my visa proxies than cohort and years since migration effects. ${ }^{16}$

\footnotetext{
${ }^{16}$ The 1993 survey does not ask about entry visa (nor work hours, patenting or publishing). The proxy visa groups I can construct are based on the educational stage at which the immigrants arrive: before college, for college, for graduate school, and after completing all education abroad.
} 


\section{Results}

I begin by outlining how immigrants fare collectively compared with natives, before considering how the various entry visa groups perform for each outcome, and turning to performance by current visa status.

\subsection{Performance by nativity}

In this section, I estimate simplified versions of equations (1) and (2), with only three elements in $I_{i}$ : immigrant, born outside the United States of American parents, and born in a U.S. territory. In Table 5, I report the coefficient or marginal effect on the immigrant dummy for each outcome.

I begin with wages in Panel A. Column 1 shows that unconditionally, immigrants (who have been in the United States at least three years) earn 2.9\% more than natives. However, simply controlling for field of study of highest degree is sufficient to flip the sign (column 2): immigrants earn $4.5 \%$ less than natives with a similar field of study. As immigrants are more educated as well as having studied more lucrative fields, controlling for education in column 3 increases the immigrant disadvantage to $8.1 \%$. Controlling for gender, race and age in column 4 improves the immigrant relative standing slightly, due to gender and race (immigrants and natives are close in age): immigrants are much less likely to be white non-hispanics, and within field of study, more likely to be female. ${ }^{17}$ Controlling for self-employment and tenure in column 5 reduces immigrants' disadvantage because immigrants have lower tenure. Finally, controlling for census region in column 6 increases immigrants' disadvantage to 8.2\%: immigrants live disproportionately in high-wage regions. Controlling for region may lead the immigrants' disadvantage to be overstated, as it may pick up genuine regional productivity differences of college graduates, and not merely price levels: California college graduates, for example, may

\footnotetext{
${ }^{17}$ Order matters here: unconditionally, immigrants are more male than natives, so gender has a big effect reducing immigrants' advantage if controlled for first. However, the gender effect is really a field of study effect.
} 
genuinely be more productive than college graduates elsewhere.

In Panel B, I examine the probability of having a patent granted. The unconditional immigrant advantage is 1.1 percentage points in column 1, equal to the mean patenting propensity of $1.1 \%$. However, $90 \%$ of the advantage is explained by field of study (column 2). By comparison, the covariates added in the subsequent columns have little effect on the gap, which becomes small and statistically insignificant. The results for having commercialized or licensed a patent are similar in Panel C: the unconditional immigrant advantage of 0.7 percentage points is equal to the mean propensity (column 1), but the advantage is almost entirely explained by field of study (column 2).

In Panel D, I turn to the probability of having published book or paper or written a paper presented at a major conference. The immigrant advantage of 3.2 percentage points is modest compared with the mean of $14.8 \%$ (column 1). Half the advantage is explained by field of study (column 2), and after controlling for education, immigrants have a statistically significant disadvantage of 1.6 percentage points (column 3). The covariates added in subsequent columns have little impact on the gap. The results for the probability of publishing a lot (more than six publications and papers) in Panel E are somewhat different. The immigrant advantage of 3.1 percentage points is high compared to the mean of $4.0 \%$, and while one third of the advantage is explained by field of study (column 2), and most of the rest by education (column 3), immigrants do retain a statistically significant though small advantage of $0.3-0.4$ percentage points with more covariates.

Because it is rare for a start-up to reach an employment level of ten workers within five years, the standard errors are large in the examination of start-ups in Panel F. The unconditional immigrant advantage of 0.18 percentage points (column 1 ) is one third of the mean of $0.6 \%$, but the estimate is significant only at the $10 \%$ level. The point estimate falls when field of study is added in column 2 , but rises to a statistically significant 0.18 percentage points in column 3 when education is added: immigrants found a considerable number of firms despite their large share with master's and doctoral degrees, which are unusual qualifications for firm founders. This suggests a niche for immigrants in founding 
firms using specialized academic knowledge. ${ }^{18}$

\subsection{Wages by entry visa}

The point estimates on the entry visa dummies and their $95 \%$ confidence intervals from the key wage regressions are displayed in Figure 2. The information is also presented in Appendix Table 3, along with the results of further specifications. The top graph in the figure shows that the unconditional wages of those who arrived on work and student/trainee visas are high compared to those of natives. Members of the best-paid group, immigrants who arrived as post-docs, earn fully 30 log points more, while only members of the "other" student/trainee group do not earn more than natives. The wages of immigrants who arrived with green cards are similar to native wages, while those who arrived as dependents or on other temporary visas earn less than natives.

The second graph displays the results of a regression to which I add controls for field of study of highest degree: as in all subsequent graphs, I continue to order the visa groups by the unconditional wage. The effect is to shift all immigrant groups to the left: all groups have more lucrative fields of study than natives, which explains about 8-10 log points of each group's unconditional advantage.

The third graph displays the results of a regression containing controls for highest degree. For the two immigrant groups defined by their high education, those who arrived as post-docs and graduate students, controlling for education does not merely explain their wage advantage over natives, but turns their advantage into a disadvantage of 810\%. Only those who arrived on work visas and for college do not have statistically significantly lower wages than natives (those who arrived on work visas have a $3.5 \%$ advantage significant at the $10 \%$ level).

Adding further controls as in Table 5 generally changes the gap for each immigrant group in qualitatively the same way as was the case for immigrants collectively in Table 5.

\footnotetext{
${ }^{18}$ Master's degrees include MBAs, but only $14.2 \%$ of immigrants who arrived as graduate students have management and administration as the field of study for their highest degree, compared with $19.0 \%$ for natives.
} 
The most successful immigrants remain those who arrived on work visas, with an insignificant $2.6 \%$ wage advantage (see Appendix Table 3 column 6). If I further add dummies for 34 occupations, 7 firm sizes, and 6 firm types (university, public, private for-profit etc.), those who arrived on work visas have an insignificant $0.6 \%$ wage advantage over natives (this result is not reported). I have repeated all the regressions using only full-time, full-year workers, or alternatively, excluding the self-employed. These unreported results are very similar.

In the graphs of Figure 3, I focus on controls that might explain how the immigrant groups fare with respect to one another. I begin by adding age to the regression controls of the bottom graph of Figure 2, to show this has little effect on the entry visa coefficients (top graph of Figure 3). In the middle graph, I add a dummy for whether the respondent's highest degree was received at a U.S. institution, the spline for age at arrival in the United States, and controls for potential U.S. and foreign experience (a dummy for having any, and a linear term; see the Data Appendix for definitions). Holding a U.S. highest degree, age at arrival and having any foreign experience are strongly correlated, so controlling for one without the others gives misleading results. The graph shows that, had immigrants and natives received their highest degree in the same country, and had immigrants arrived shortly after birth (with no foreign experience) and acquired the same U.S. experience as natives, immigrants of all entry visas would have earned the same as or more than similar natives. The biggest coefficient increases between the top and middle graphs are for those who arrived on work visas and as post-docs, since they came to the United States at a relatively old age, and, in the case of the post-docs, with a foreign highest degree (the experience variables are less influential). The middle graph shows an enormous 36 log point wage advantage over natives for those who arrived on work visas, and a 18 log point advantage for those who arrived as post-docs. The coefficient of those who arrived as college students is relatively little affected by the additional controls, indicating that their high wages in the top graph are due to their relatively young age at arrival and their almost universally having earned their highest degree in the United States. ${ }^{19}$

\footnotetext{
${ }^{19}$ In a sample of workers of all education levels, Akee and Yuksel (2008) find the return to years of
} 
In the regression underlying the bottom graph, I control for years since migration, arrival cohort and birth region. This has little effect on the gaps between the entry visa groups (only the birth region coefficients are jointly significant, so the standard errors grow). Allowing the coefficients on the non-visa covariates of the top graph to vary according to whether the respondent is an immigrant or not also has little effect on the relative standing of the entry visa groups (these results are not shown). The results of Figure 3 suggest that immigrants have ability similar to or higher than natives, but are handicapped by language and other culture-specific skills. However, the counterfactual of admitting particular entry visa groups to the United States at a young age is not realistic, as in most cases they could only have been selected in the way they were at an older age.

It is possible that immigrants who arrived with green cards are artificially disadvantaged in the analysis compared to those who arrived on temporary visas. For immigrant couples who arrive on temporary visas, the spouse whose career is less important receives a dependent's visa and is classified separately. I have shown this latter group has low earnings. By contrast, couples who arrive with legal permanent residence both receive green cards and their earnings are grouped together in the survey. I cannot match spouses in my data. However, $69 \%$ of immigrants who arrived on a dependent's visa when aged over 18 are women, which suggests that in a sample of male immigrants only, the visa categories would be more comparable. The unconditional male wages (except for the dependent visa group) are very similar to the middle graph of Figure 2, in which I controlled for field: immigrants arriving with green cards earn statistically significantly less than natives and all student/trainee groups except "other" (these results are not reported).

\subsection{Patents granted, commercialized or licensed, by entry visa}

In Figure 4, I display marginal effects from probits for the probability of being granted a patent (the underlying numbers are reported in Appendix Table 4). The unconditional results in the top graph show that those who arrived as post-docs or graduate students foreign education to be similar to the return to years of U.S. education, but find a lower return to foreign than U.S. experience. 
have an enormous 5.3-6.6 percentage point advantage over natives, compared to a mean patenting propensity of only 1.1\%. Those who arrived on work visas or for college or on "other" student/trainee visas also have considerable advantages over natives of 1.3-2.2\%.

However, the second graph indicates that these advantages are largely explained by field of study. Those who arrived as post-docs and graduate students retain a statistically significant advantage over natives with the same field of study, but the third graph shows that this is attributable to their higher education. No immigrant group is more likely to be granted a patent than natives with the same degree and field of study, and those who arrived as green card holders, on dependent and other temporary visas have lower patenting propensities than natives.

The marginal effects are very similar in the top graph of Figure 5, where I control for age. In the regression underlying the middle graph, I control for the age at arrival spline, for having received the highest degree in the United States and for potential foreign and U.S. experience. These controls do not have the large effects on the rankings of immigrant groups they had in the case of wages, and the standard errors become very large, as the age at arrival coefficients (jointly) and holding a U.S. highest degree are insignificant. In the bottom graph, I control for years since migration, arrival cohort and birth region, which increases the standard errors still further, again without changing much the ordering of the immigrant groups. Allowing interactions of the top graph covariates with a dummy for immigrant likewise has little effect on the ranking of the immigrant groups (these results are not reported).

I repeat the main regressions for the probability of commercializing or licensing a patent, and display the results in Figures 6 (see also Appendix Table 5). The qualitative patterns are the same as for the probability of being granted a patent, though the magnitudes of the marginal effects are smaller, commensurate with the smaller mean of the outcome $(0.7 \%)$. For both patenting and commercializing and licensing patents, restricting the sample to men has little effect on the unconditional relative patenting propensities of the different groups. 


\subsection{Publications and papers by entry visa}

In Figure 7, I present the marginal effects from probits for the probability of publishing a book or paper or writing a paper presented at a conference (see also Appendix Table 6). The top graph shows the enormous unconditional advantages over natives enjoyed by immigrants who arrived as post-docs (53 log points) and immigrants who arrived as graduate students (27 log points), compared to the mean propensity of $14.8 \%$. The members of these two immigrant groups by definition had research as a major activity when they arrived in the United States, so this is not a surprise. More interestingly, immigrants who arrived on work visas, for college or for other study or training also have statistically significant advantages over natives of approximately 5 percentage points. Immigrants who arrived with a green card perform worse than natives, while the dependent and other temporary visa categories are statistically indistinguishable from natives. The unreported results for men only are similar.

In the middle graph, I display the results of the regression controlling for field of study. This control does not explain much of the gaps between groups. By contrast, the higher education of the student/trainee and work visa groups explains most of their publication advantage over natives, as shown in the bottom graph. Three groups are left with a higher publication propensity than natives: immigrants who arrived for graduate school, for other study or training, or as post-docs. The publishing advantage of the latter group is equal to the mean at $14 \log$ points. Appendix Table 6 columns 4 and 5 show that much of the advantage of the graduate school and "other" student/trainee groups is explained by current enrollment and employment at a university, while most of the advantage of the post-docs remains after these controls. Adding controls for highest degree interacted with field leaves the gaps between groups similar (these results are not reported).

In Figure 8 I examine the probability of having more than six publications or papers (see also Appendix Table 7). The results for the unconditional probability (top graph) and the probability conditional on field (middle graph), are qualitatively the same as the for the probability of any publication in Figure 7, though the magnitudes of the marginal 
effects are somewhat smaller (the mean is considerably smaller, at 4.0\%, making the gaps between the groups larger relative to the mean). The unreported results for men only are similar. However, after controls for field of study and highest degree, in the bottom graph, immigrants who arrived on work visas, as post-docs, as graduate students and as other students/trainees retain statistically significant advantages over natives of 1.3-7.0 percentage points. These advantages are not explained by student status or employment at a university (see Appendix Table 7 columns 4 and 5), nor by the interaction of field and highest degree (these results are not reported).

In the regression underlying the top graph of Figure 9, I add age controls to the regression underlying the bottom graph of Figure 8, which has little effect. Controlling for U.S. highest degree, the age at arrival spline, and foreign and U.S. experience in the middle panel serves mainly to increase the standard errors, as does controlling for years since migration, arrival cohort and birth region in the bottom panel. Interacting an immigrant dummy with the covariates of the regression underlying the top graph has little effect on the relative standing of the entry visa groups (these results are not reported).

\subsection{Start-ups of successful companies by entry visa}

In Figure 10 I display the results of regressions for the probability of starting a company with ten or more employees (see also Appendix Table 8). The top graph shows that although the work visa and student/trainee groups have point estimates that are large compared with the mean start-up propensity of $0.6 \%$, the standard errors are too large to distinguish any of the immigrants groups from natives or one another. This remains true in the middle graph, which displays the results of a regression with controls for field of study. However, controlling for education in the regression behind the bottom graph increases the marginal effect of immigrants who arrived as graduate students considerably, to a statistically significant 1.2 percentage point advantage over natives. As mentioned above, these results point to such immigrants having a niche in start-ups founded on advanced technical knowledge. 


\subsection{Performance by current visa status}

I now turn to analyzing performance by current, rather than entry, visa status. In Table 6, I show how the sample is divided by current visa status. A majority of immigrants are naturalized U.S. citizens (in either the wage sample, column 1, or the patent and publication sample, column 3), and most immigrants are either naturalized or have green cards. The samples of dependents of temporary visa holders and holders of other temporary visas are small, as is the sample of working students, and I present little further information on them. The lower panel shows that most work visa holders either entered the United States on a work visa $(42 \%)$, or entered on a student/trainee visa $(46 \%)$. I focus my remarks on holders of student/trainee and work visas, since it is not clear how or which green card holders choose to naturalize. ${ }^{20}$

Column 2 of Table 6 shows that the highest-earning visa group is work visa holders who entered the United States as such ("new work visa holders"). Naturalized citizens also earn more than natives, while work visa holders who entered as students/trainees ("U.S.-educated work visa holders") earn about the same as natives. I also show the shares of each current visa group which patent and which publish frequently (I focus on frequent publishing to reduce the likelihood of capturing old student publications by workers no longer publishing), but these means are more easily seen in the graphs below.

In Table 7, I provide selected means for the main current visa categories, which highlight large differences between the two main work visa categories. While $65 \%$ of new work visa holders have only a bachelor's degree (column 1), the same share as natives, only $17 \%$ of the U.S.--educated work visa holders had only a bachelor's degree, making them the most educated group. The U.S.-educated work visa holders are more likely to have studied biological sciences compared to engineering (columns 2 and 3), and if working, are very likely to work at a four-year college or university: column 6 shows that $25 \%$ do so. Columns 4 and 5 show that, as expected, holders of temporary visas are younger and

\footnotetext{
${ }^{20}$ I therefore do not analyze firm start-ups as most temporary visa holders are not permitted to own companies. I cannot subdivide the current student/trainee group for reasons of sample size.
} 
have been in the United States fewer years than green card holders or naturalized citizens (or natives, in the case of age).

I analyze the determinants of wages by current visa in Table 8, presenting the coefficients only on the visa categories of most interest. Columns 1 and 2 show that while work visa holders collectively earn $6.0 \%$ more than natives, they are at a $6.9 \%$ disadvantage once education, field of study and age are taken into account. In the remaining columns I split the work visa holders into their constituent groups. Unconditionally, new work visa holders earn fully $18.2 \%$ more than natives, while U.S.--educated work visa holders earn an insignificant $2.8 \%$ more (column 3). Controlling for field of study has a large effect in column 4 , reducing the new work visa advantage to $4.7 \%$, and turning the U.S.-educated work visa advantage into an $8.9 \%$ disadvantage. Controlling for education in column 5 has little effect on the new work visa advantage, as this group has similar education to natives, but has a large effect on the highly-educated U.S.--educated work visa group, increasing the disadvantage to $24.9 \%$. However, immigrants on temporary visas are younger than natives, so in column 6, where I introduce controls for age, the new work visa advantage rises to $8.5 \%$ and the U.S.--educated work visa disadvantage shrinks to $15.1 \%$.

I follow the existing literature by controlling successively for more covariates in columns 7-9, which reduces the new work visa coefficient somewhat without having much effect on the U.S.-educated work visa coefficient. In column 9, where I control for demographics, enrollment status, tenure, self-employment, region, occupation and firm characteristics (including working in a four-year college or university), new work visa holders maintain a $3.6 \%$ advantage over natives (albeit now statistically insignificant), while U.S.-educated work visa holders languish at a $13.2 \%$ disadvantage compared to natives. This is consistent with the results of Figure 2, which showed that those who entered on a work visa had the highest conditional wages of any entry visa group, equal to conditional native wages, despite their relatively old age upon arrival in the United States and their foreign education. It is thus not necessary to appeal to rapid assimilation or to selective emigration to explain the later success of those initially on temporary visas: they are high earners from the time of their arrival. Finally, in column 10, I control for the age at arrival spline, 
U.S. highest degree and potential U.S. and foreign experience. Consistent with Figure 3, new work visa holder wages are much higher (22.7 log points) than native wages when adjusted to reflect arrival shortly after birth and a U.S. highest degree. For U.S.--educated work visa holders, while half the wage disadvantage is explained and the coefficient becomes insignificant, the point estimate remains negative, unlike the corresponding case in Figure 3 .

In Figure 11 I present results for the probability of patenting. The two main work visa groups have statistically indistinguishable positive coefficients only slightly lower than the mean patenting propensity of $1.1 \%$. However, the slightly smaller coefficient of the new work visa holders is not significant (if all work visa holders are grouped, their patenting propensity is a statistically significant 0.66 percentage points higher than that of natives). The $95 \%$ confidence interval for student/trainee visa holders is too large to make comparisons with other groups. After I control for field of study, in the middle graph, and education, in the bottom graph, both main work visa groups and student/trainee visa holders have statistically significantly lower patenting probabilities than natives, and the three groups are not statistically significantly different from each other. Unlike in the case of wages, for patenting the addition of age controls does not affect the relative standing of the visa groups, so I do not present these results.

In Figure 12, I perform the same exercise for the probability of frequent publishing, whose mean is $4.0 \%$. Students and U.S.--educated work visa holders are an enormous 22-28 percentage points more likely to publish frequently than natives, while even the statistically significantly smaller advantage of new work visa holders, at 6.4 percentage points, is still large (top graph). These advantages are reduced by controls for field of study (middle graph) and education (bottom graph), but students retain a 15.3 percentage point advantage over natives, and the two main work visa groups retain a 4.1-4.3 percentage point advantage, though this is significant only for the U.S.--educated work visa holders. If all work visa holders are grouped, their frequent publishing propensity is a statistically significant 3.7 percentage points higher than natives' (this result is not graphed). As in the case of patents, controlling for age changes the results little, and I do not present 
these results.

Table 6 and Figures 11 and 12 have shown that while it is essential to distinguish new and U.S.--educated work visa holders for the purposes of wages, the distinction is much less important for patenting and frequent publishing. Both groups have a higher unconditional patenting propensity than natives, which is consistent with the entry visa results (high standard errors due to a small sample size preclude comparing current stu-

dents/trainees with those who entered on a student/trainee visa). Conditional on field of study and education, current students/trainees and both current work visa groups patent less than natives, whereas by entry visa, students/trainees and work visa holders were indistinguishable from natives (c.f. Figures 4 and 11). I can control for years since migration to assess whether those currently on work visas will catch up to natives once they have been in the United States as long as those who entered on work visas. This does not appear to be the case (these results are not reported), but questions of assimilation, cohort effects and selective emigration are not well dealt with in a single cross-section. Both current work visa groups and current students/trainees are more likely to publish frequently than natives, both conditionally and unconditionally. This is qualitatively consistent with the results by entry visa (c.f. Figures 8 and 12), though current students/trainees publish even more relative to natives than do former students (those who entered on a student/trainee visa).

\section{Conclusions}

Using the 2003 National Survey of College Graduates, I show that immigrants who originally entered the United States on temporary work visas or on student/trainee visas outperform native college graduates in wages, patenting, commercializing and licensing patents and authoring books or papers for publication or presentation at major conferences. I also find that, conditional on education, these immigrants are more likely than natives to start a successful company, suggesting that immigrants have a niche in startups based on technical knowledge from master's and doctoral degrees. Immigrants who 
arrived as legal permanent residents (principally through family unification) perform similarly to natives, while those who arrived as dependents of temporary visa-holders or on other temporary visas perform worse than natives. The results suggest a ranking of the gross contribution of immigrant groups according to their status on arrival in the United States: postdoctoral fellows and medical residents; graduate students; temporary work visa holders; college students; other students/trainees; legal permanent residents; dependents of temporary visa holders; and other temporary visa holders.

The success of skilled immigrants is determined by a combination of immigrant selfselection in wanting to come to the United States, the entry visa framework provided by the government, the behavior of U.S.--based agents who select immigrants applying for particular visas, immigrant self-selection in wanting to remain in the United States, and the visa framework for remaining. I conclude that within this complex system, firms, universities and teaching hospitals are the most successful in attracting and selecting immigrants engaged in activities likely to increase U.S. total factor productivity. By contrast, natives and immigrants already in the United States sponsor college-educated immigrant spouses and family members who perform similarly to college-educated natives.

For most outcomes and entry visa groups, the work and student/trainee visa immigrant advantage is explained by immigrants' higher education and field of study. U.S. firms, universities and teaching hospitals are thus identifying high-quality immigrants based mainly on their educational credentials, rather than on superior innate creative or inventive abilities. However, even compared to similar natives, three of the four student/trainee groups retain an advantage in authoring books or papers for publication or presentation at major conferences. Also, although immigrants who arrived as college students perform similarly on all outcomes to similarly educated natives, universities do identify immigrant college students who, if they stay in the United States, eventually obtain more education than native college students. Compared to similar natives, immigrants who entered as legal permanent residents perform worse on all outcomes except company start-ups.

One element of a cost-benefit analysis of the net contribution of each immigrant 
group to natives is savings to the United States from immigrant education completed and financed abroad. However, I show that this foreign education does come at a price to the United States: foreign education commands a lower wage return in the U.S. labor market, and the more foreign education an immigrant has, the older he or she is upon arrival in the United States, which further reduces wages and productivity. Only immigrants who arrived as college students (due to their young age at arrival and U.S. degrees) and immigrants who arrived on temporary work visas earn as much as similar natives. All entry visa groups would earn the same as or more than similar natives had they arrived as children and acquired U.S. degrees. Holding a foreign highest degree has no impact on patenting and authoring books or papers, and age at arrival has a weaker influence on these outcomes than on wages.

In my analysis of outcomes by current visa status, I confirm the crucial nature of the distinction made by Lowell and Avato (2007), between temporary work visa holders who entered the United States as such, and those who entered on student/trainee visas. The former group out-earns natives both conditionally and unconditionally, while the latter highly-educated group has unconditional wages similar to natives', but earns much less than natives conditional on education. These results underscore the insights gained by classifying immigrants according to entry visa. 


\section{References}

Akhee, Randall and Mutlu Yuksel. 2008. "A Note on Measures of Human Capital for Immigrants: Examining the American Community Survey and New Immigrant Survey". IZA Discussion Paper 3897.

Anderson, Stuart and Michaela Platzer. 2006. "American Made: The Impact of Immigrant Entrepreneurs and Professionals on U.S. Competitiveness". National Venture Capital Association.

Bleakley, Hoyt and Aimee Chin. 2004. "Language Skills and Earnings: Evidence from Childhood Immigrants". Review of Economics and Statistics, 86(2) pp. 481-496.

Borjas, George J. 2006a. "Do Foreign Students Crowd Out Native Students from Graduate Programs?". In Ronald G. Ehrenberg and Paula E. Stephan eds. Science and the University, Madison: University of Wisconsin Press.

Borjas, George J. 2006b. "Immigration in High-Skill Labor Markets: The Impact of Foreign Students on the Earnings of Doctorates". NBER Working Paper 12085.

Borjas, George J. 2002. "An Evaluation of the Foreign Student Program". Center for Immigration Studies Backgrounder.

Borjas, George J. 1995. "Assimilation and Changes in Cohort Quality Revisited: What Happened to Immigrant Earnings in the 1980s?" Journal of Labor Economics, 13(2) pp. 201-245.

Chellaraj, G. Keith E. Maskus and A. Mattoo. 2008. "The Contribution of Skilled Immigration and International Graduate Students to U.S. Innovation". Review of International Economics, 16 (3) pp. 444-462.

Eaton, Jonathan and Sam Kortum. 1999. "International Technology Diffusion: Theory and Measurement". International Economic Review, 40(3) pp. 537-570.

Fairlie, Robert W. 2008. "Estimating the Contribution of Immigrant Business Owners to the U.S. Economy", Small Business Bureau working paper.

Finn, Michael G. 2005. "Stay Rates of Foreign Doctorate Recipients from U.S. Universities, 2003", Oak Ridge Institute for Science and Education working paper. orise.orau.gov/sep/files/stayrate05.pdf, accessed 29 March 2009.

Finn, Michael G. 2000. "Stay Rates of Foreign Doctorate Recipients from U.S. Universities, 1997", Oak Ridge Institute for Science and Education working paper. orise.orau.gov/sep/files/stayrate00.pdf, accessed 29 March 2009.

Hira, Ron. 2007. "Outsourcing America's technology and knowledge jobs: High-skill guest worker visas are currently hurting rather than helping keep jobs at home". Economic Policy Institute Briefing Paper 187. 
Hunt, Jennifer and Marjolaine Gauthier-Loiselle. 2009. "How Much Does Immigration Boost Innovation?" CEPR Working Paper 7116.

Jasso, Guillermina, Mark R. Rosenzweig, and James P. Smith. 2000. "The Changing Skill of New Immigrants to the United States: Recent Trends and Their Determinants." In George J. Borjas ed., Issues in the Economics of Immigration. Chicago, IL: University of Chicago Press.

Kahn, Shulamit and MacGarvie, Megan. 2008. "How Important is U.S. Location for Research in Science?". Boston University working paper.

Kerr, William R. 2007. "The Ethnic Composition of U.S. Inventors". Harvard Business School Working Paper No. 08-006.

Kerr, William R and William Lincoln. 2008. "The Supply Side of Innovation: H-1B Visa Reforms and U.S. Ethnic Invention". Harvard Business School working paper.

Kirkegaard, Jacob Funk. 2007. "The Accelerating Decline in America's High-Skilled Workforce: Implications for Immigration Policy". Peterson Institute for International Economics, Policy Analyses in International Economics 84.

Lowell, B. Lindsay and Johanna Avato. 2007. "The Wages of Skilled Temporary Migrants: Effects of Visa Pathways and Job Portability". Georgetown University working paper.

Lubotsky, Darren. 2007. "Chutes or Ladders? A Longitudinal Analysis of Immigrant Earnings". Journal of Political Economy 115 (5) pp. 820-867.

Massey, Douglas S. and Nolan Malone. 2002. "Pathways to Legal Immigration". Population Research and Policy Review 21(6) pp. 473-504.

Matloff, Norman. 2008. "H-1Bs: Still Not the Best and the Brightest". Center for Immigration Studies Backgrounder.

Miano, John. 2007. "Low Salaries for Low Skills: Wages and Skill Levels for H-1B Computer Workers, 2005". Center for Immigration Studies Backgrounder.

Mithas, Sunil and Henry C. Lucas. 2008. "Does High-skill Immigration Make Everyone Better Off? United States Visa Policies and Compensation of Information Technology Professionals". University of Maryland working paper.

Morgan, Robert P., Carlos Kruytbosch and Nirmala Kannankutty. 2001. "Patenting and Invention Activity of U.S. Scientists and Engineers in the Academic Sector: Comparisons with Industry". Journal of Technology Transfer, 26 pp. 173-183.

Paserman, Daniele M. 2008. "Do High-Skill Immigrants Raise Productivity? Evidence from Israeli Manufacturing Firms, 1990-1999". IZA Discussion Paper 3572. 
Peri, Giovanni. 2007. "Higher Education, Innovation and Growth". In Giorgio Brunello, Pietro Garibaldi and Etienne Wasmer eds. Education and Training in Europe, Oxford: Oxford University Press.

Peri, Giovanni and Chad Sparber. 2008. "Highly Educated Immigrants and Occupational Choice" U.C. Davis working paper.

Schaafsma, Joseph and Arthur Sweetman. 2001. "Immigrant earnings: age at immigration matters". Canadian Journal of Economics, 34(4) pp. 1066-1099.

Stephan Paula E. and Sharon G. Levin. 2001. "Exceptional contributions to US science by the foreign-born and foreign-educated". Population Research and Policy Review, 20 pp. 59-79.

Stuen, Eric T., Ahmed Mushfiq Mobarak and Keith E. Maskus. 2007. "Foreign PhD Students and Knowledge Creation at U.S. Universities: Evidence from Enrollment Fluctuations". University of Colorado working paper.

Sweetman, Arthur and Casey Warman. 2008. "Temporary Foreign Workers and Former International Students as a Source of Permanent Immigration". Queen's University working paper.

Wadhwa, Vivek, Guillermina Jasso, Ben Rissing, Gary Gereffi and Richard Freeman. 2007. "Intellectual Property, the Immigration Backlog and a Reverse Brain-Drain". Kauffman Foundation report.

Wadhwa, Vivek, AnnaLee Saxenian, Ben Rissing and Gary Gereffi. 2007. "America's New Immigrant Entrepreneurs". Kauffman Foundation report. 


\section{Data Appendix}

I use individual-level data from the 2003 National Survey of College Graduates (NSCG). The data may be downloaded at sestat.nsf.gov/datadownload/. The survey is a stratified random sample of respondents to the 2000 census long form who reported having a bachelor's degree or higher. Immigrants arriving between April 2000 and October 2003 are not in the sampling frame. I drop respondents who live outside the United States or in U.S. territories, or who are aged 65 or older (the youngest respondent is 23 , but few are younger than 26). I include in all samples those who are self-employed on their principal job.

My wage sample is based on respondents working at the time of the survey. I do not make any exclusions based on hours worked. The survey asks for "basic annual salary" on the principal job, and instructs "Do not include bonuses, overtime or additional compensation for summertime teaching or research". The self-employed are directed to "estimate earned income, excluding business expenses". There are no negative salary values. I compute hourly wages by dividing the annual salary by the number of weeks it was based on and by the usual weekly hours on this job. I drop 1636 observations with missing or zero wage values and observations with hourly wage values below $\$ 5.15$, the federal minimum wage in 2003 (1457 observations). I also drop observations with a high hourly wage for respondents who looked likely to have confused annual weeks and months, or weekly and daily hours (the heaping patterns suggest such confusion exists): I drop observations with hourly wages of more than $\$ 100$ if weekly hours are nine or less or annual weeks are twelve or less (739 observations). I cannot drop observations with imputed values, as these are not flagged. However, I drop from the wage sample the 379 remaining observations with an annual salary of $\$ 565,172$, a value I strongly suspect of being imputed (the next largest annual salary is $\$ 360,000$ ). These wage-based sample restrictions account for the difference in size between the wage sample $(75,940)$ and the firm start-up sample $(80,151)$. In my robustness check using full-time, full-year workers, I use workers with 50-52 weeks per year and 35 hours per week or more. The sample for patenting and for authoring books or papers is based on respondents who had ever worked, and has 90,293 observations.

I define a respondent as having founded a company if he or she responded that his or her principal employer came into being as a new business within the past five years, that his or her principal employer was self-employed in the survey week (incorporated or not), and that counting all locations where this employer operated, it had more than ten employees. I compute potential U.S. experience as years since the award of the highest degree if the degree was obtained in the United States or by a non-immigrant, or as years in the United States if the highest degree was obtained abroad by an immigrant. I compute potential foreign experience as the difference between the year of arrival in the United States and the year of the award of highest degree for immigrants receiving their highest degree abroad, zero for others. The computation resulted in a small number of immigrants with negative potential foreign experience: I set these values to zero.

To assess whether in the census too immigrants out-earn natives among college grad- 
uates, I use weighted individual data from the 2000 census. As in the NSCG, I separate respondents born abroad of American parents and in U.S. territories from the immigrant and native categories. I restrict the sample to ages 25-64 and compute hourly wages both based on wage and salary income in 1999 and on all earned income in 1999. The census does not separate either income or hours by job. Immigrants and natives in the census earn the same hourly wages based on all earned income, but immigrants earn $1 \%$ more when immigrants who have been in the United States less than three years are dropped. Immigrants have $2 \%$ higher hourly wages based on wage and salary income with recent immigrants excluded. This is a smaller advantage than the 4-5\% advantage calculated in the NSCG for either all workers or workers without the self-employed (the log wage advantage analyzed in the paper is smaller). 

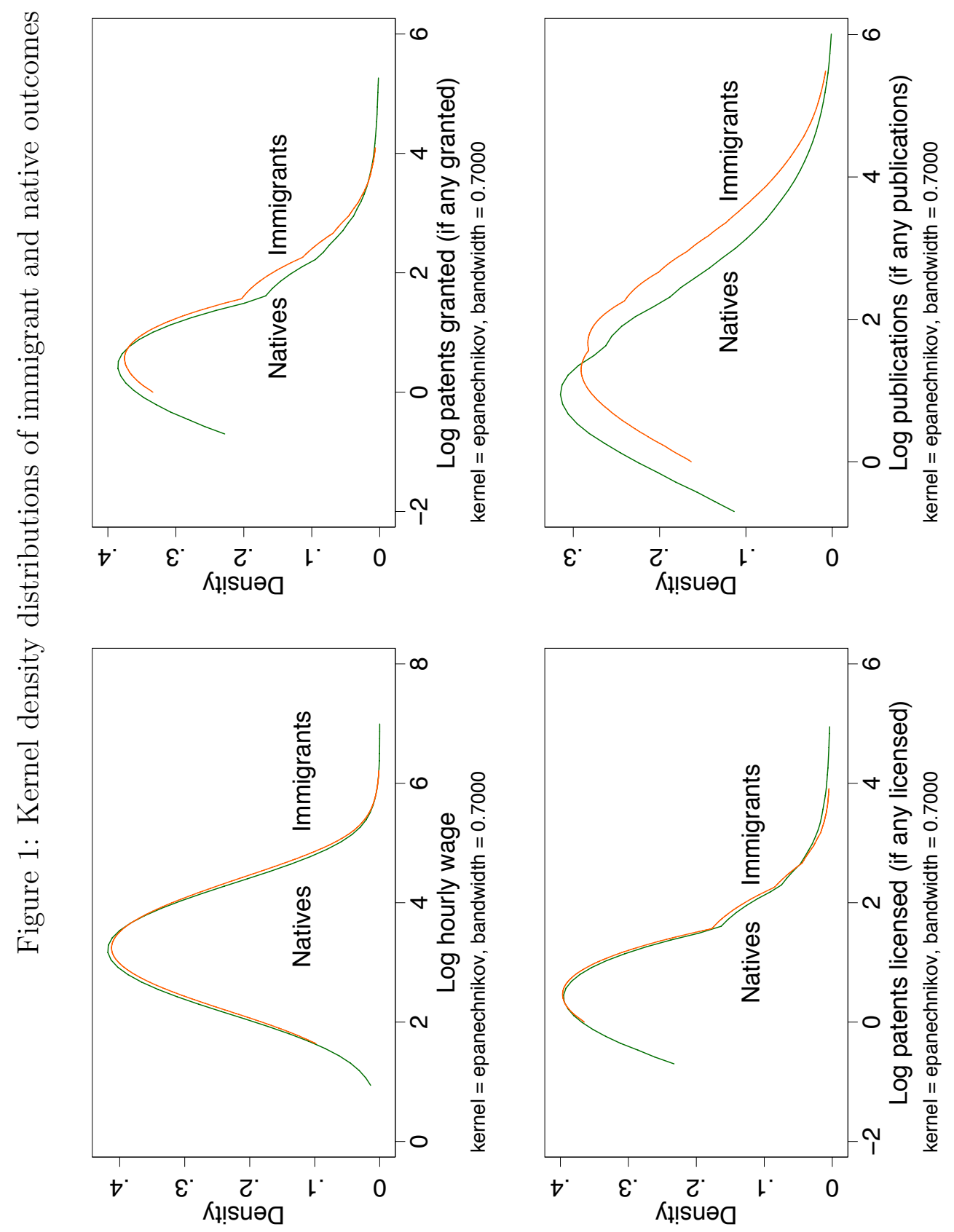

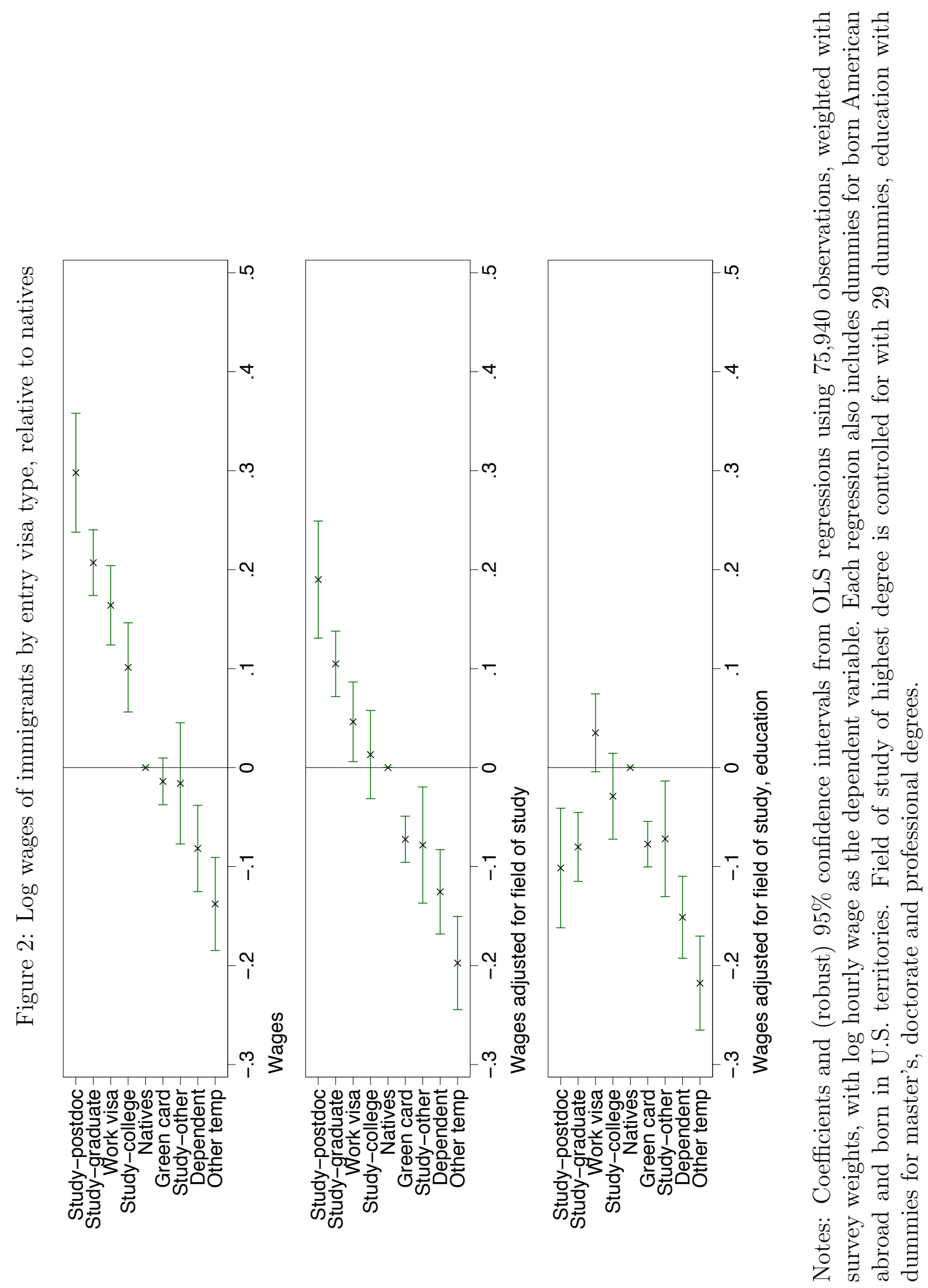

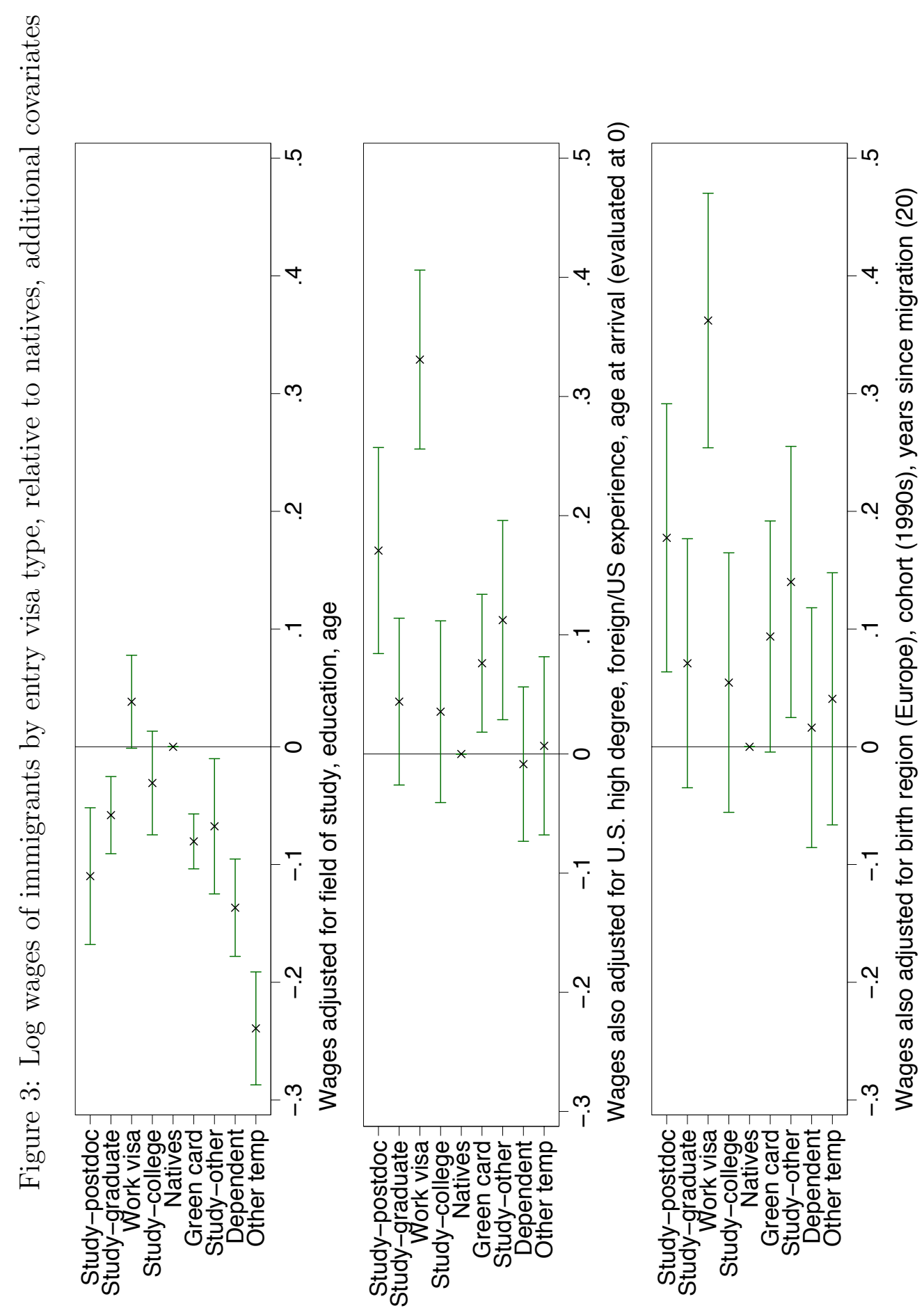

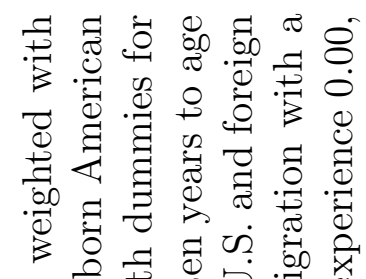

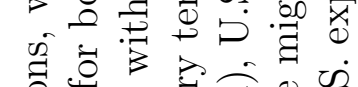

.

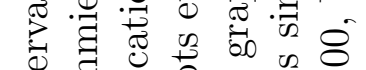

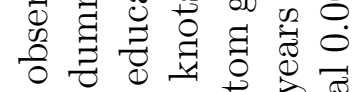
0 o $斤$\begin{tabular}{l} 
\pm \\
\hline
\end{tabular}

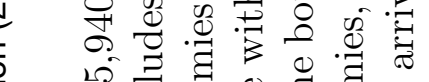
ㅇㅝㄹㅀ so. 更 क क . D $\quad$ की

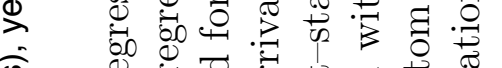

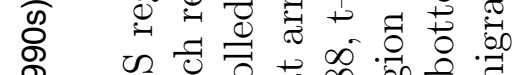

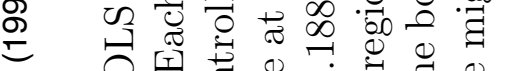

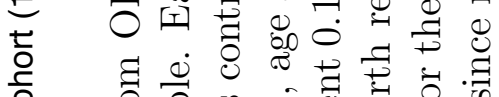

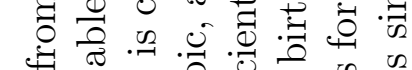

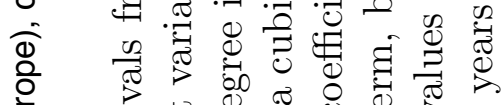

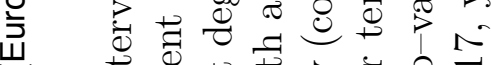

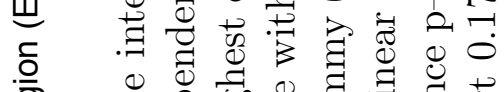
ن 过

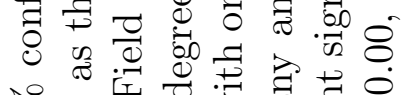

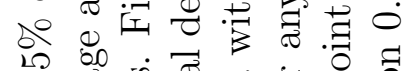
ڤ

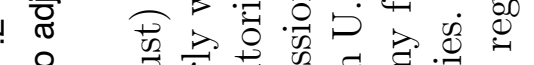

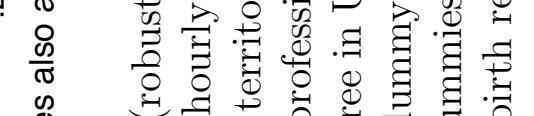

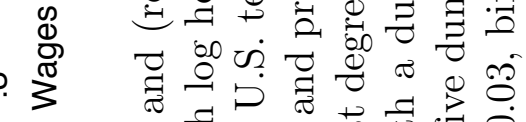

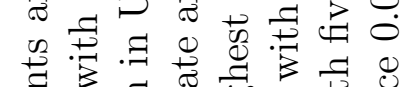

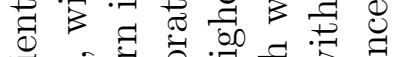

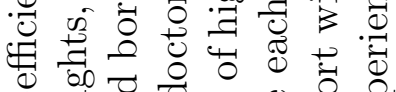

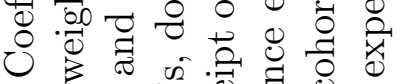
$\ddot{y} \dot{0} \overrightarrow{0}$

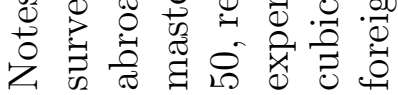



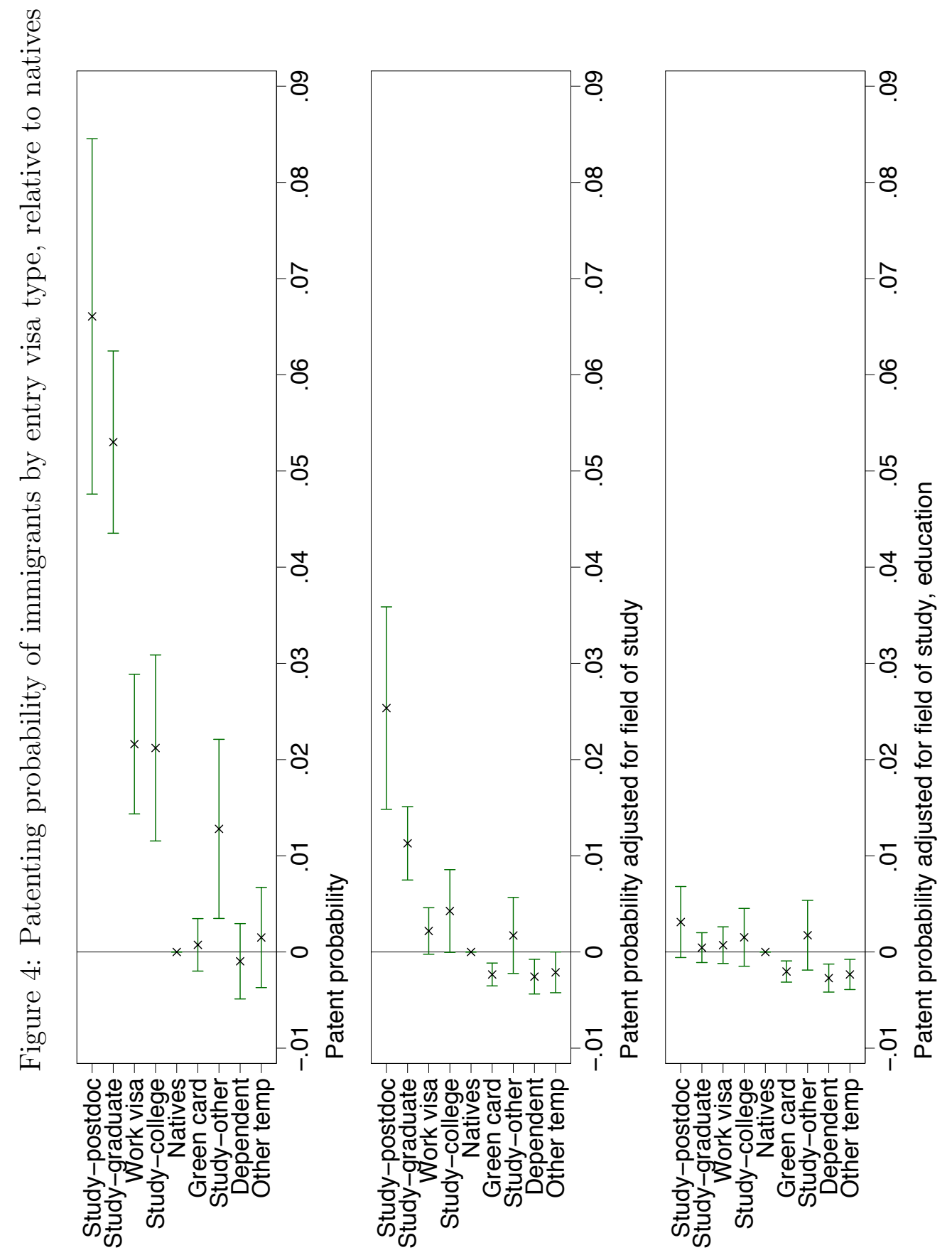

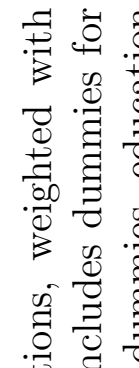

莡 0

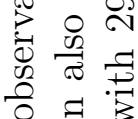

भ.

ᄋ 50

क $=$

吾矛兘

过 0.0

जी

$50>-$

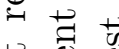

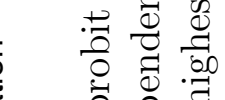

뉴ㅇㅝㅠ

켱 0 ○

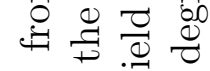

के

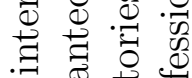

४ 50.

造的完

రํ워

造苛

- -80

कृ च क

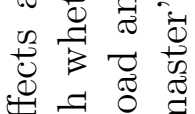

両秀

สี

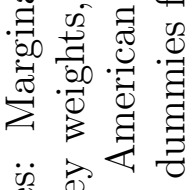

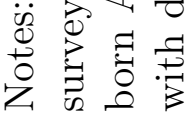




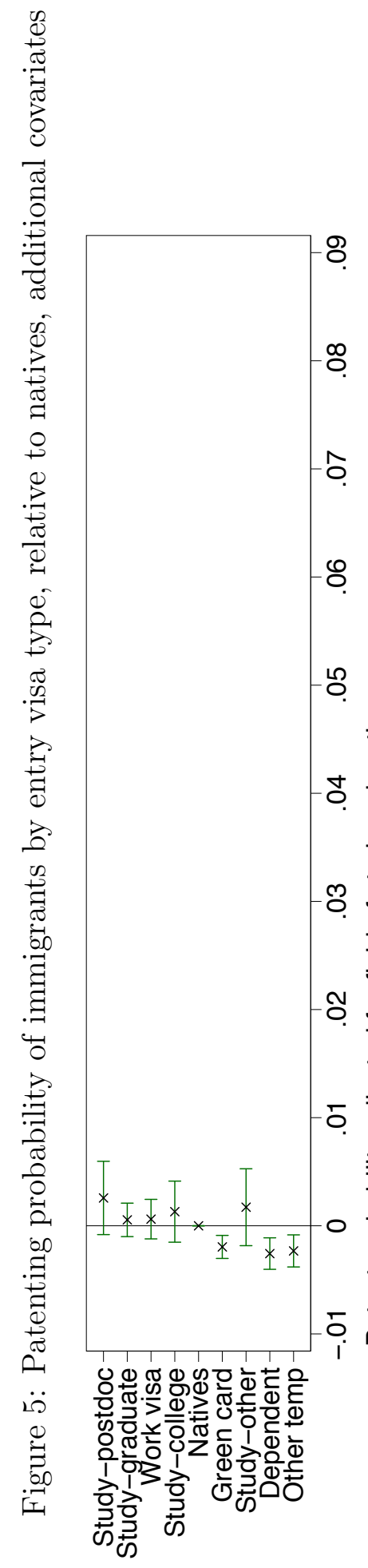

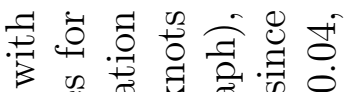

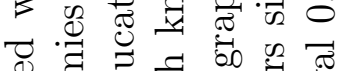

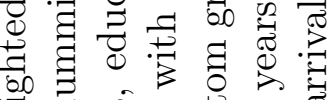

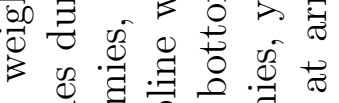

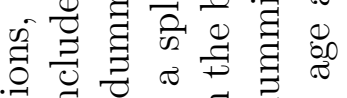

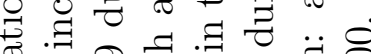

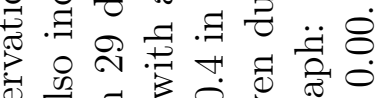

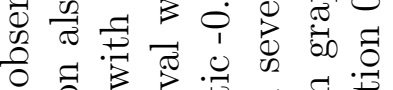

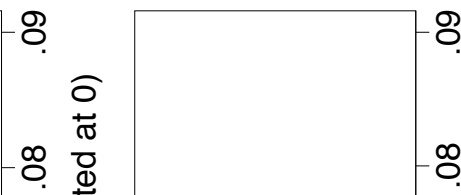

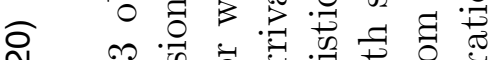

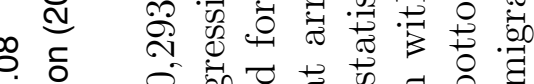
施

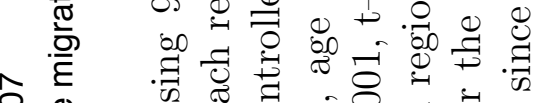
○.

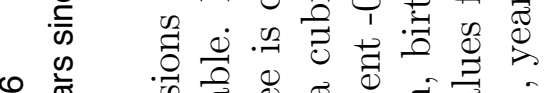

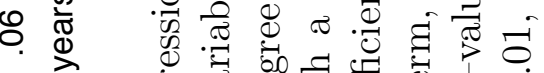

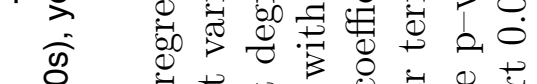

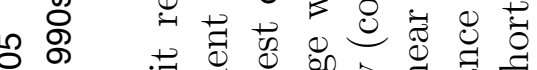
ᄃ $\quad$ 过

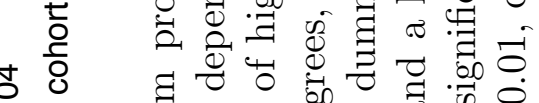

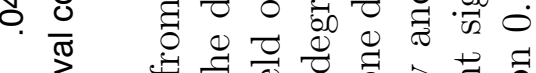

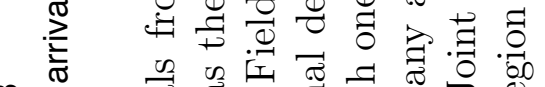
\%

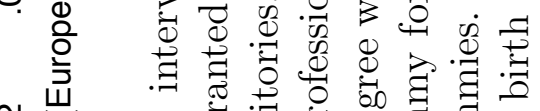
๙ิ ब б

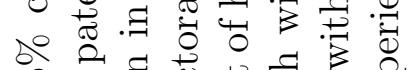

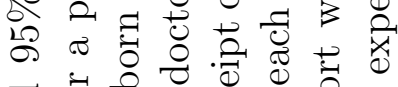
चี

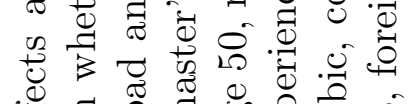
- $\frac{\circ}{4}$

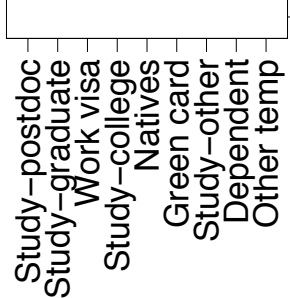
$111-\bar{j}_{i} \frac{8}{4}$

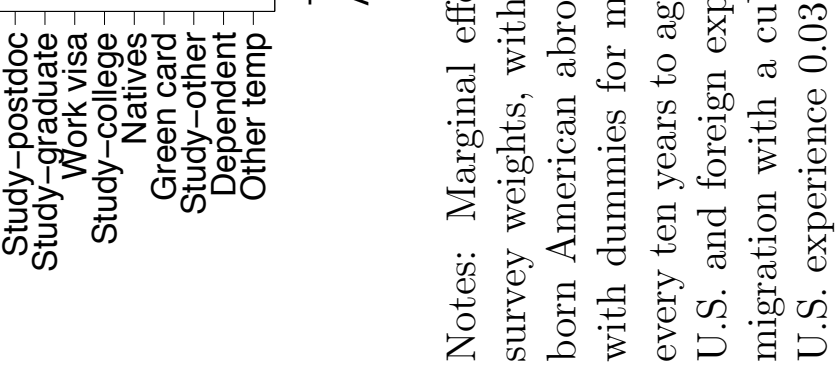



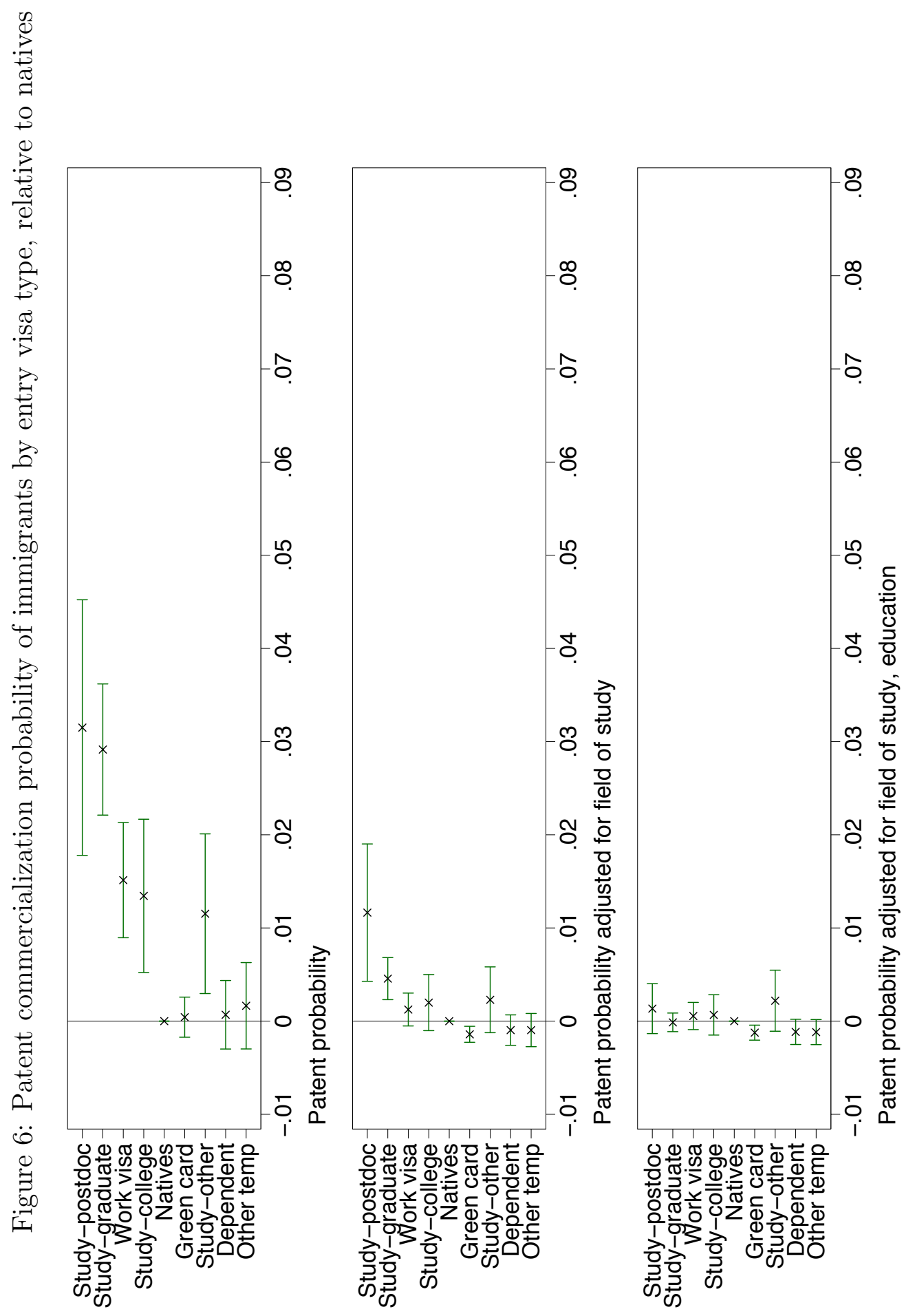

곤

ช..$\overline{\mathrm{T}}$

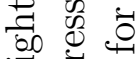

ए 50

$s=0$

की

范

ن.

卷.

$\circledast \frac{\pi}{\square}$

है प्च पु

50 व .00

$\exists$.

웡

a 0 드

苛古密

के

क

․ㅜㅇ. 붕

至:

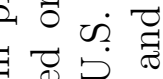

:

के

更

흐 몀

ᄒ 8 व

-

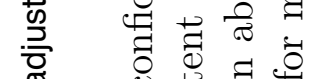

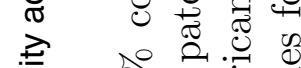

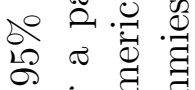

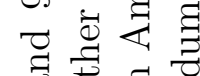

की

象带富

สำ

.

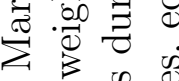

$\ddot{0}$ 仓

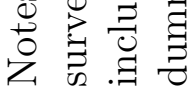



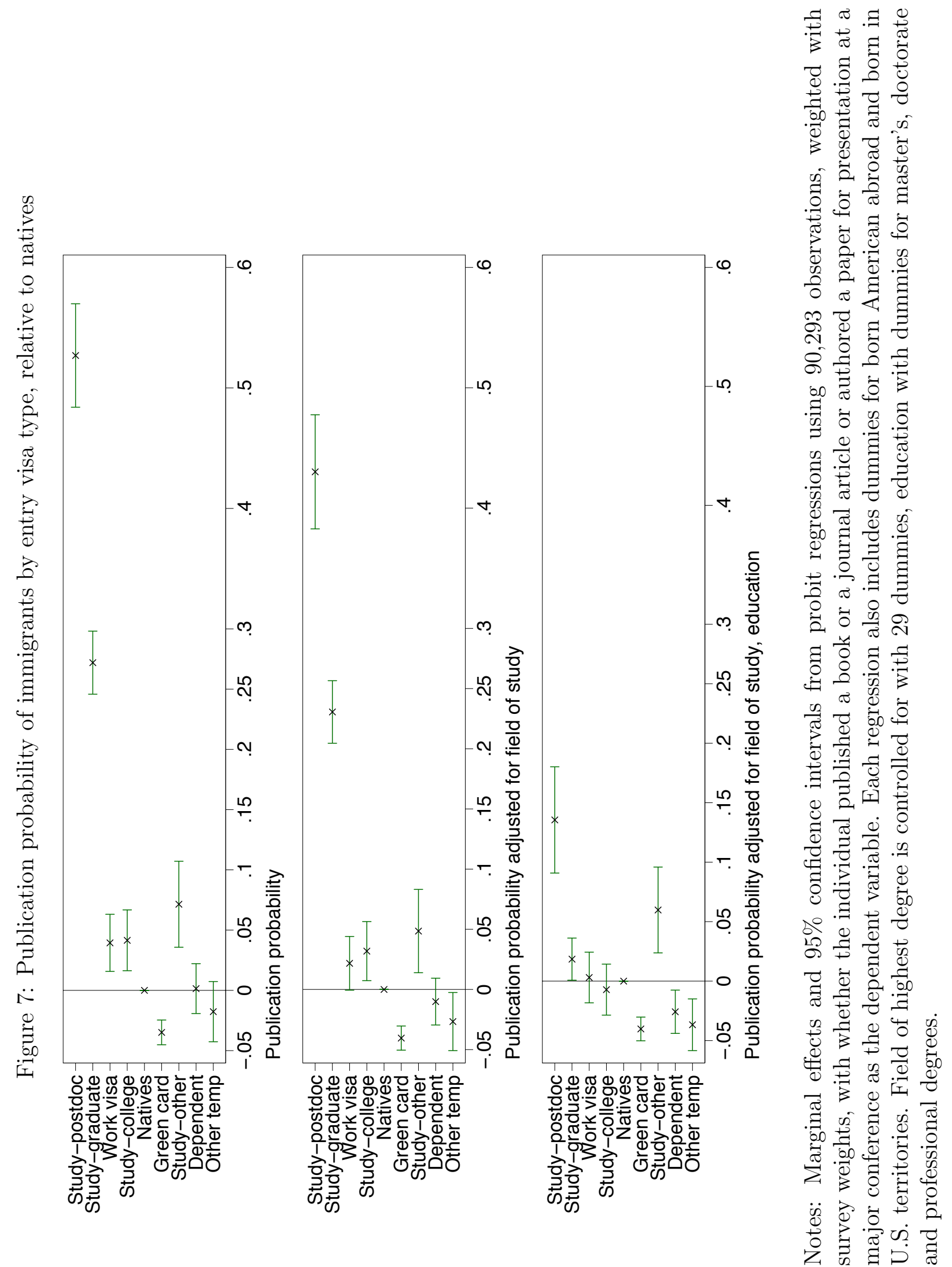

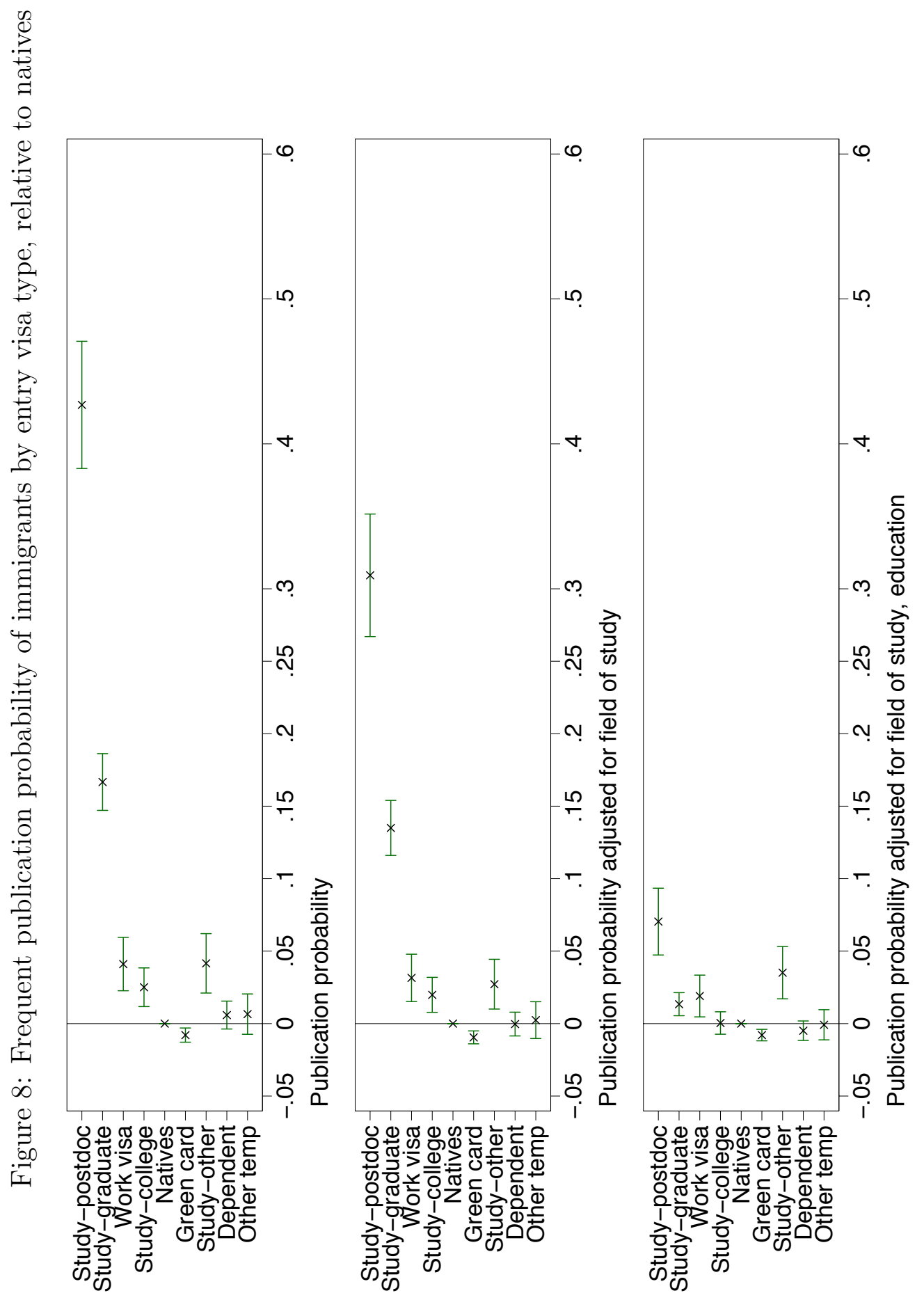

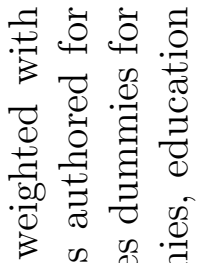

3 o

के

궁

嵌

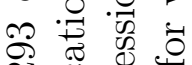

8:

め) 궁

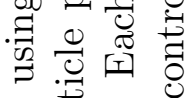

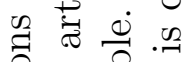

号

0 政

$\circ . \circ+7$

昰苛

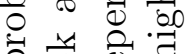

a 1 :

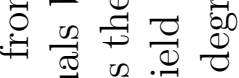

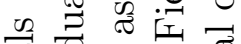

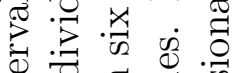

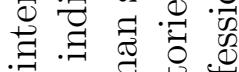

ه $\nabla$.

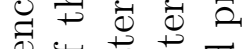

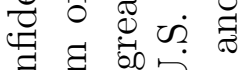

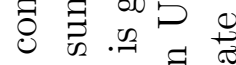

so 过

12

-

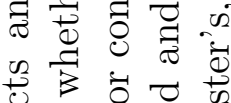

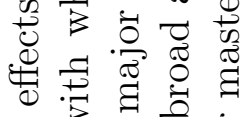

उ $\bar{\sigma} \approx$

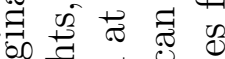

ส․ .00.

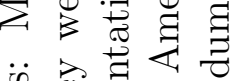

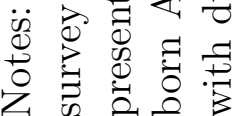




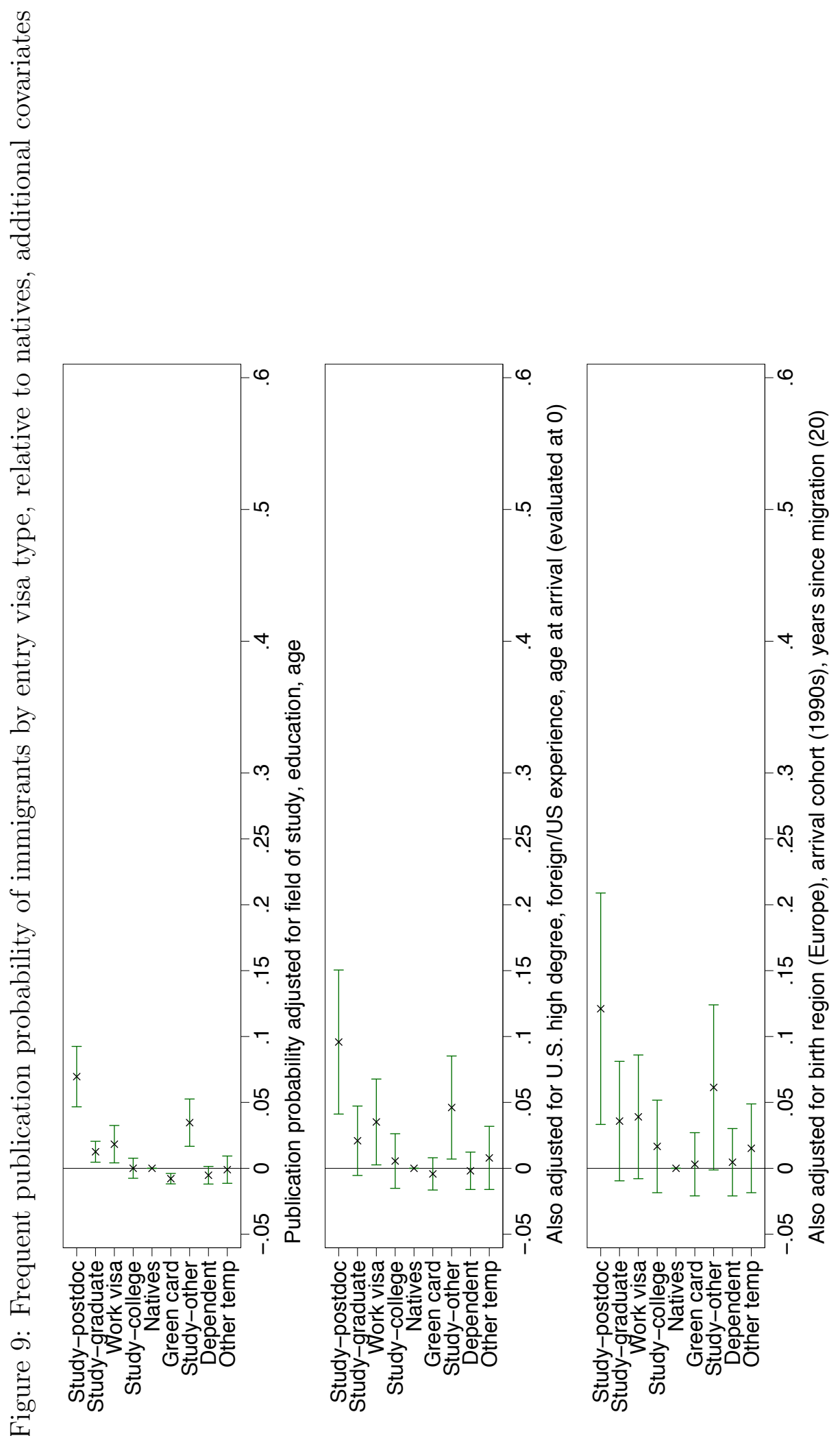

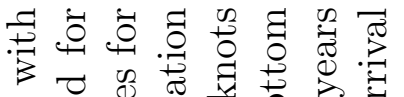

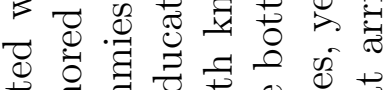

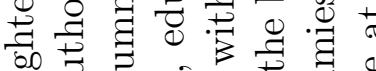

च छ क

额 过

की

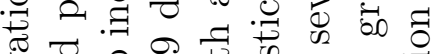

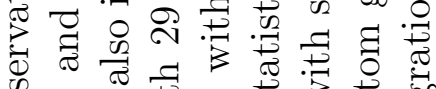

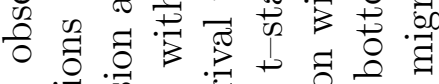

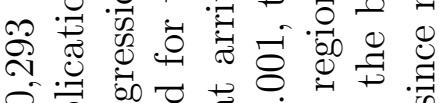

\&

b

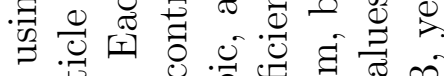

ด 0.0 .0

त. उ० $\$ 0$

क

ธ大

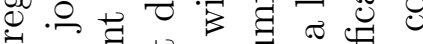

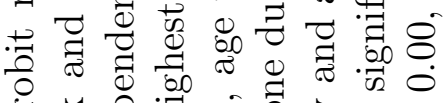

花

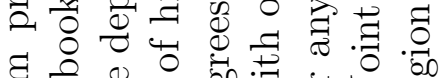

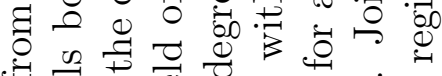

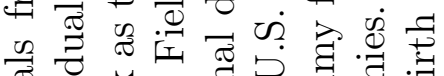

क

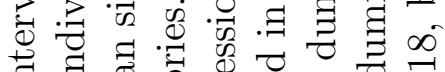

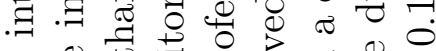

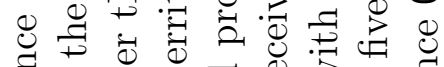

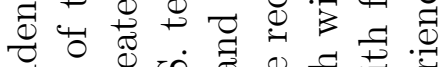

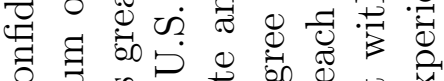

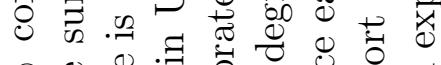

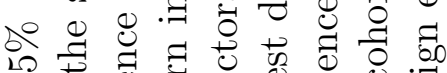

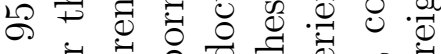

$\tau$ च

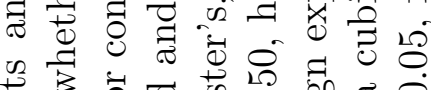

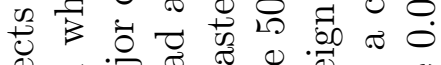

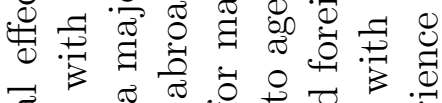

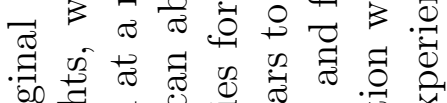

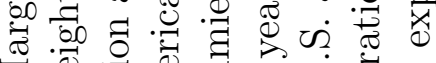

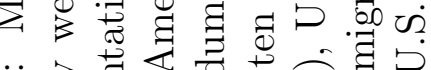

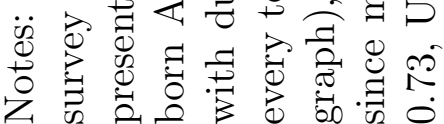



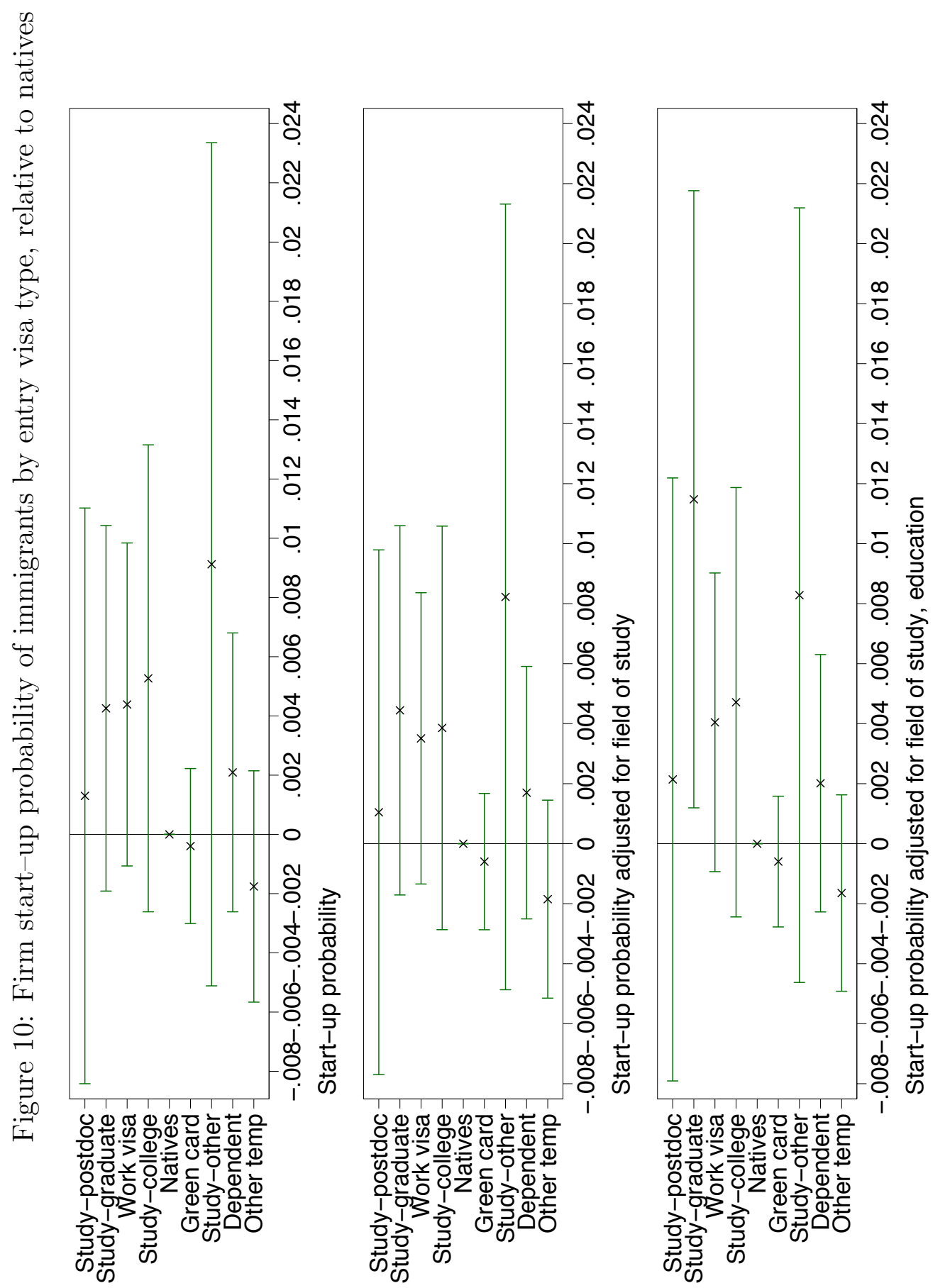

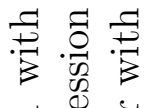

ठृ 50

类

$\$$

की

응

雨

क्ष

言

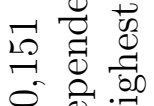

更

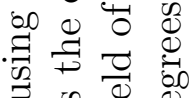

๘

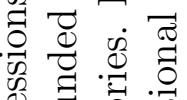

. 0 .

计

तै

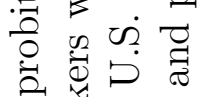

:

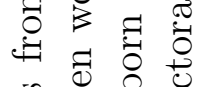

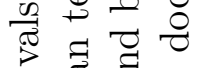

రิ త్రి

言 ఫ

. 000

㐘

음 돈 훙

हี

¿

过它毛

용 $\approx$

चี

告专

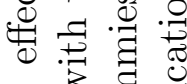

శే

की मै की की

离 $\frac{0}{0}$

$\ddot{0}$ 过导

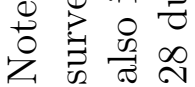



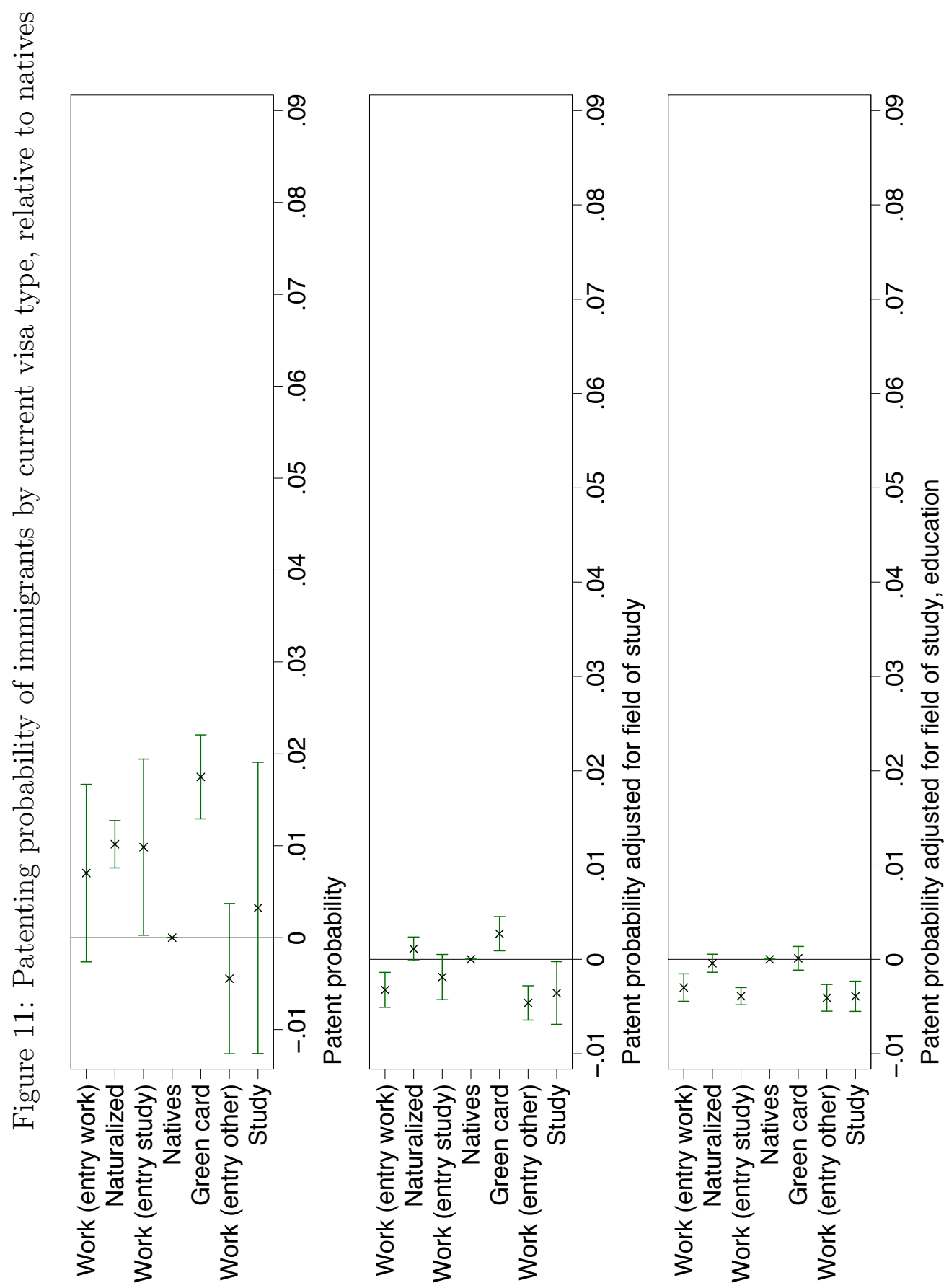

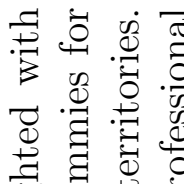

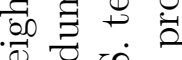

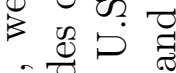

क $\Xi \Xi 0$

㠰

요용

嵌

$0 \approx$ क

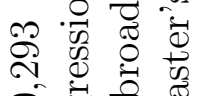

\&

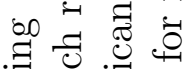

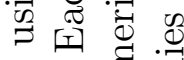

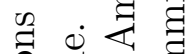

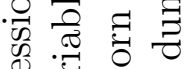

$50 ; 0$

记

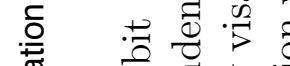

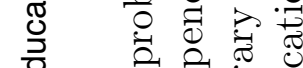

\& च च च

ते

क

흔 矛焉

히듀

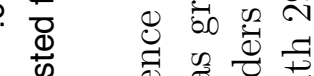

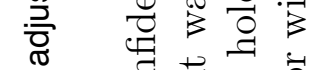

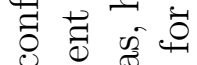

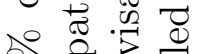

in

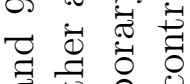

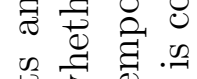

告高过

象击

$\widetilde{\sigma} \overline{0}$

की

के .000

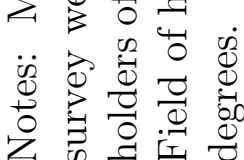




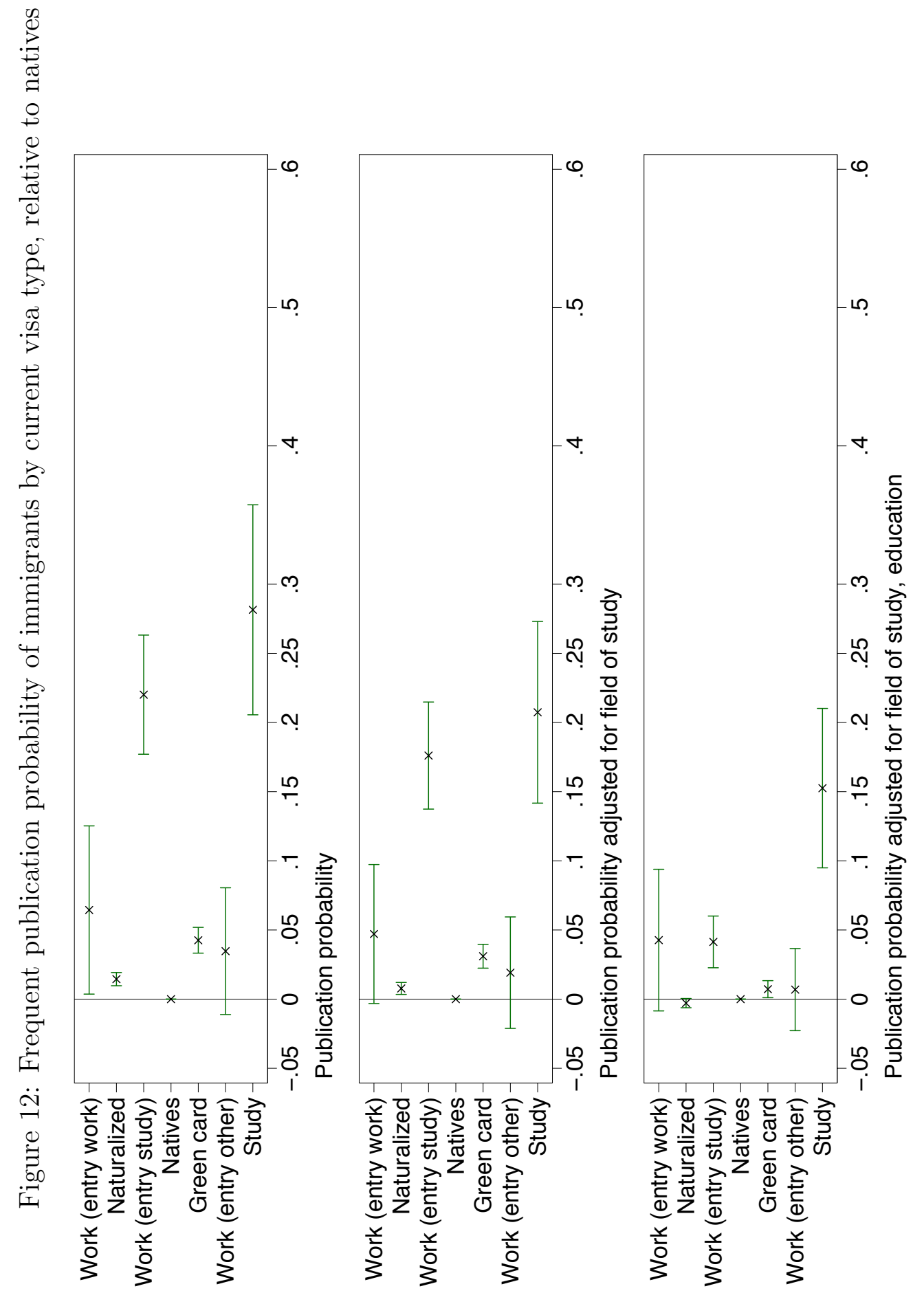

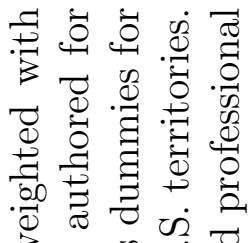
उ. की

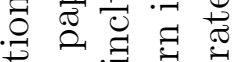
记 员 n 0.0 क 赵 \& $\infty$ है दี శี $\exists 0 \widetilde{G}$ 马.

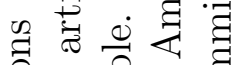
. 0 政

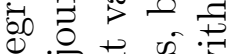
$\rightarrow$ 정

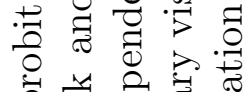

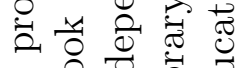
묘응

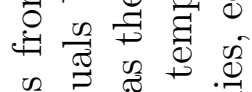
तै

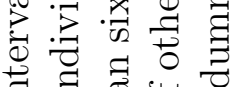
: $\exists$ चु

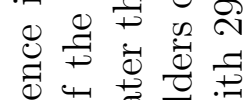

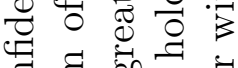
ठี द्व कर की e $0.0 \%$ 设吉

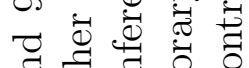

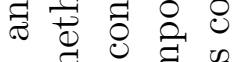

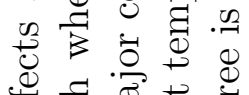

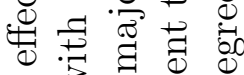
구 $\approx$

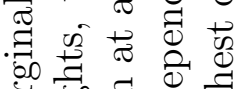

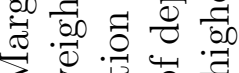

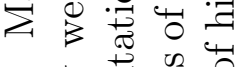

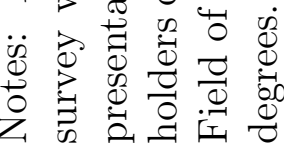


Table 1: Shares of natives and immigrants by entry visa

\begin{tabular}{|lcccc|}
\hline & $\begin{array}{c}(1) \\
\text { Wage sample } \\
(\%)\end{array}$ & $\begin{array}{c}(2) \\
\text { Start-up sample } \\
(\%)\end{array}$ & $\begin{array}{c}(3) \\
\text { Patent and publication sample } \\
(\%)\end{array}$ \\
\hline U.S. native & 86.3 & 85.9 & 86.4 & -- \\
Born American abroad & 1.2 & 1.6 & 1.1 & -- \\
Born in U.S. territories & 0.3 & 0.3 & 0.3 & -- \\
Green card & 5.2 & 5.2 & 5.2 & 43.1 \\
Work, temporary & 1.6 & 1.5 & 1.5 & 12.0 \\
Study/training, temporary & & & & 24.3 \\
$\quad$ - for college & 0.9 & 0.9 & 0.9 & -- \\
$\quad$ - for graduate school & 1.3 & 1.2 & 0.3 & -- \\
$\quad$ - for post-doc & 0.3 & 0.3 & 0.7 & -- \\
$\quad$ - for other & 0.7 & 0.7 & 1.4 & 11.6 \\
Dependent, temporary & 1.3 & 1.3 & 1.1 & 9.0 \\
Other temporary & 1.1 & 1.1 & 100 & 100 \\
Observations & 100 & 100 & \multicolumn{2}{c|}{90,293} \\
\hline
\end{tabular}

Notes: Shares weighted with survey weights. The wage and start-up samples include those working in the survey reference week. The patent and publication sample includes those who have ever worked. Patents, publications and start-ups are for the five years prior to the survey week. Publications include published books or journal articles or papers authored for regional, national or international conference presentations. 
Table 2: Weighted means of outcomes by entry visa

\begin{tabular}{|c|c|c|c|c|c|c|}
\hline & \multirow{2}{*}{$\begin{array}{c}\text { (1) } \\
\text { Hourly } \\
\text { wage } \\
(\$)\end{array}$} & \multirow{2}{*}{$\begin{array}{c}(2) \\
\text { Started firm } \\
\text { with more than } \\
\text { ten workers }(\%)\end{array}$} & \multicolumn{2}{|c|}{$\begin{array}{l}(3) \\
\text { Any patent }(\%)\end{array}$} & \multicolumn{2}{|c|}{$\begin{array}{lc}(5) & (6) \\
\text { Publication }(\%)\end{array}$} \\
\hline & & & $\begin{array}{l}\text { Any } p \\
\text { Granted }\end{array}$ & $\begin{array}{l}\text { Commer- } \\
\text { cialized }\end{array}$ & & $\begin{array}{l}\text { Mon }(\%) \\
\text { More } \\
\text { than six }\end{array}$ \\
\hline \multicolumn{7}{|l|}{ A. Immigrant vs native } \\
\hline U.S. native & 29.6 & 0.6 & 0.9 & 0.6 & 14.4 & 3.6 \\
\hline Immigrant & 30.7 & 0.8 & 2.0 & 1.3 & 17.6 & 6.8 \\
\hline American born abroad & 29.3 & 0.8 & 1.3 & 0.9 & 18.4 & 4.2 \\
\hline Born in U.S. territories & 28.1 & 0.3 & 0.6 & 0.3 & 17.2 & 3.1 \\
\hline \multicolumn{7}{|l|}{ B. Entry visa type } \\
\hline Green card & 29.7 & 0.6 & 1.0 & 0.6 & 11.0 & 2.9 \\
\hline Work & 34.2 & 1.0 & 3.0 & 2.0 & 18.3 & 7.6 \\
\hline Dependent & 27.9 & 0.8 & 0.8 & 0.6 & 14.5 & 4.2 \\
\hline Other temporary & 26.0 & 0.4 & 1.1 & 0.7 & 12.6 & 4.3 \\
\hline \multicolumn{7}{|l|}{ Study/training } \\
\hline - for college & 32.4 & 1.1 & 2.9 & 1.9 & 18.5 & 6.1 \\
\hline - for graduate school & 35.1 & 1.0 & 6.1 & 3.4 & 41.5 & 20.1 \\
\hline - for post-doc & 40.4 & 0.7 & 7.2 & 3.6 & 67.0 & 45.8 \\
\hline - for other & 29.6 & 1.5 & 2.1 & 1.7 & 21.4 & 7.7 \\
\hline Observations & 75,940 & 80,151 & & & & \\
\hline
\end{tabular}

Notes: Means weighted with survey weights. Publications include published books or journal articles or papers authored for regional, national or international conference presentations. 
Table 3: Weighted means of field of study of highest degree by entry visa ( $\%)$

\begin{tabular}{|lccccccc|}
\hline & $\begin{array}{c}(1) \\
\text { CS, } \\
\text { Math }\end{array}$ & $\begin{array}{c}(2) \\
\text { Biological } \\
\text { science }\end{array}$ & $\begin{array}{c}(3) \\
\text { Physical } \\
\text { science }\end{array}$ & $\begin{array}{c}(4) \\
\text { Social } \\
\text { science }\end{array}$ & $\begin{array}{c}(5) \\
\text { Eng- } \\
\text { ineering }\end{array}$ & $\begin{array}{c}(6) \\
\text { S\&E } \\
\text { related }\end{array}$ & $\begin{array}{c}(7) \\
\text { S\&E }\end{array}$ \\
\hline A. Immigrant vs native & & & & & & & \\
U.S. native & 3.6 & 4.0 & 1.7 & 10.8 & 5.3 & 12.2 & 62.4 \\
Immigrant & 8.5 & 5.5 & 3.7 & 9.1 & 14.4 & 16.8 & 41.9 \\
Born American & 3.6 & 6.0 & 2.1 & 11.8 & 8.5 & 13.8 & 54.2 \\
abroad & & & & & & & \\
Born U.S. territories & 3.9 & 4.5 & 1.8 & 9.3 & 8.2 & 14.3 & 58.1 \\
\hline B. Entry visa type & & & & & & & \\
Green card & 5.5 & 4.3 & 3.2 & 9.4 & 11.8 & 18.1 & 47.7 \\
Work & 13.8 & 3.2 & 3.7 & 7.0 & 21.9 & 18.8 & 31.7 \\
Dependent & 9.0 & 6.6 & 2.7 & 13.0 & 8.3 & 14.7 & 45.7 \\
Other temporary & 6.8 & 4.9 & 3.3 & 10.0 & 12.2 & 16.2 & 46.5 \\
Study/training & & & & & & & \\
$\quad$ - for college & 9.8 & 4.7 & 2.2 & 7.3 & 18.8 & 12.0 & 45.1 \\
$\quad$ - for grad school & 16.8 & 9.7 & 6.8 & 6.2 & 25.1 & 8.7 & 26.8 \\
$\quad$ - for post-doc & 3.7 & 24.2 & 11.6 & 1.3 & 3.6 & 50.4 & 5.1 \\
$\quad$ - for other & 6.9 & 6.5 & 4.9 & 11.8 & 14.2 & 15.8 & 39.8 \\
\hline
\end{tabular}

Notes: Means of patenting and publishing sample, 90,293 observations, weighted with survey weights. The rows sum to 100. "S\&E" means science and engineering. S\&E related is principally health. 
Table 4: Weighted means of other covariates by entry visa (\%, except ages)

\begin{tabular}{|lccccccc|}
\hline & $\begin{array}{c}(1) \\
\text { Bachelor's }\end{array}$ & $\begin{array}{c}(2) \\
\text { Master's }\end{array}$ & $\begin{array}{c}(3) \\
\text { Doc- } \\
\text { torate }\end{array}$ & $\begin{array}{c}(4) \\
\text { Prof- } \\
\text { essional }\end{array}$ & $\begin{array}{c}(5) \\
\text { Age }\end{array}$ & $\begin{array}{c}(6) \\
\text { Age at } \\
\text { arrival }\end{array}$ & $\begin{array}{c}\text { U.S. highest } \\
\text { degree }\end{array}$ \\
\hline A. Immigrant vs native & & & & & & & \\
U.S. native & 65.0 & 26.0 & 2.9 & 6.2 & 44.4 & -- & 99.6 \\
Immigrant & 56.5 & 28.6 & 7.7 & 7.2 & 43.3 & 23.3 & 55.5 \\
Born American & 63.3 & 25.7 & 3.2 & 7.8 & 41.6 & -- & 95.9 \\
abroad & & & & & & & \\
Born U.S. territories & 62.7 & 26.7 & 4.4 & 6.1 & 42.5 & -- & 98.5 \\
\hline B. Entry visa type & & & & & & & \\
Green card & 67.1 & 22.5 & 2.7 & 7.7 & 44.2 & 21.0 & 56.9 \\
Work & 61.6 & 28.6 & 6.0 & 3.8 & 42.0 & 29.7 & 17.6 \\
Dependent & 60.4 & 27.3 & 4.8 & 7.4 & 40.8 & 18.0 & 60.4 \\
Other temporary & 62.8 & 25.2 & 3.8 & 8.3 & 44.8 & 27.4 & 35.7 \\
Study/training & & & & & & & \\
$\quad$ - for college & 53.2 & 34.6 & 7.7 & 4.6 & 42.9 & 21.5 & 97.9 \\
$\quad$ - for grad school & 0 & 63.7 & 33.2 & 3.1 & 42.3 & 26.0 & 100.0 \\
$\quad$ - for post-doc & 0 & 0 & 51.0 & 49.0 & 46.2 & 29.7 & 0.0 \\
$\quad$ - for other & 68.5 & 26.4 & 2.3 & 2.9 & 42.6 & 23.4 & 37.6 \\
\hline
\end{tabular}

Notes: Means of patenting and publishing sample, 90,293 observations, weighted with survey weights. Master's degrees include MBAs. 
Table 5: Nativity differences in hourly wages, patents, publications, start-ups

\begin{tabular}{|c|c|c|c|c|c|c|}
\hline & $(1)$ & $(2)$ & (3) & $(4)$ & $(5)$ & $(6)$ \\
\hline \multicolumn{7}{|c|}{ A. Log wages $(75,940$ obs $)$} \\
\hline \multirow[t]{2}{*}{ Immigrant } & 0.029 & -0.045 & -0.081 & -0.066 & -0.049 & -0.082 \\
\hline & $(3.7)$ & $(-5.8)$ & $(-10.5)$ & $(-8.6)$ & $(-6.4)$ & $(-10.7)$ \\
\hline R-squared & 0.00 & 0.07 & 0.13 & 0.17 & 0.19 & 0.21 \\
\hline \multicolumn{7}{|c|}{ B. Any patent granted $(90,293 \mathrm{obs} ;$ mean $=1.1 \%)$} \\
\hline \multirow[t]{2}{*}{ Immigrant } & 0.0112 & 0.0011 & -0.0007 & -0.0003 & -0.0003 & -- \\
\hline & $(12.3)$ & $(2.2)$ & $(-1.8)$ & $(-1.0)$ & $(-1.0)$ & \\
\hline R-squared & 0.01 & 0.15 & 0.19 & 0.22 & 0.22 & -- \\
\hline \multicolumn{7}{|c|}{ C. Any patent licensed or commercialized $(90,293$ obs; mean $=0.7 \%)$} \\
\hline \multirow[t]{2}{*}{ Immigrant } & 0.0070 & 0.0005 & -0.0004 & -0.0001 & -0.0000 & -- \\
\hline & $(9.7)$ & $(1.3)$ & $(-1.3)$ & $(-0.2)$ & $(-0.2)$ & \\
\hline R-squared & 0.01 & 0.15 & 0.18 & 0.20 & 0.2 & -- \\
\hline \multicolumn{7}{|c|}{ D. Any publication or paper $(90,293$ obs; mean=14.8\%) } \\
\hline \multirow[t]{2}{*}{ Immigrant } & 0.032 & 0.016 & -0.016 & -0.016 & -0.019 & -- \\
\hline & $(8.4)$ & $(4.1)$ & $(-4.1)$ & $(-4.1)$ & $(-5.1)$ & \\
\hline R-squared & 0.00 & 0.03 & 0.11 & 0.12 & 0.14 & -- \\
\hline \multicolumn{7}{|c|}{ E. More than six publications or papers $(90,293$ obs; mean $=4.0 \%)$} \\
\hline \multirow[t]{2}{*}{ Immigrant } & 0.031 & 0.021 & 0.004 & 0.004 & 0.003 & -- \\
\hline & $(15.3)$ & $(11.1)$ & $(2.5)$ & $(2.8)$ & $(2.1)$ & \\
\hline R-squared & 0.01 & 0.04 & 0.18 & 0.19 & 0.22 & -- \\
\hline \multicolumn{7}{|c|}{ F. Any start-up $(80,151$ obs; mean $=0.6 \%)$} \\
\hline \multirow[t]{2}{*}{ Immigrant } & 0.0018 & 0.0013 & 0.0018 & 0.0020 & 0.0021 & -- \\
\hline & $(1.9)$ & $(1.6)$ & $(2.1)$ & $(2.4)$ & $(2.4)$ & \\
\hline R-squared & 0.00 & 0.02 & 0.02 & 0.03 & 0.03 & -- \\
\hline Field highest degree & -- & Yes & Yes & Yes & Yes & Yes \\
\hline Highest degree & -- & -- & Yes & Yes & Yes & Yes \\
\hline Sex, age, race & -- & -- & -- & Yes & Yes & Yes \\
\hline Currently enrolled & -- & -- & -- & -- & Yes & Yes \\
\hline $\begin{array}{l}\text { Tenure, } \\
\text { self-employed }\end{array}$ & -- & -- & -- & -- & Yes (A) & Yes (A) \\
\hline $\begin{array}{l}\text { Working, working } \\
\text { at university }\end{array}$ & -- & -- & -- & -- & Yes (D) & -- \\
\hline Region & -- & -- & -- & -- & -- & Yes $(A)$ \\
\hline
\end{tabular}

Notes: Coefficients from least squares regressions (panel A) or marginal effects from probits (panels B-F), weighted with survey weights. Robust t-statistics are reported in parentheses. Each coefficient or marginal effect is from a different regression, and in each case the omitted category is U.S. native. Each regression also includes dummies for Born American abroad and for those born in U.S. territories. Field of highest degree is controlled for with 29 dummies ( 28 in panels D and F), highest degree with dummies for master's, doctorate and professional degrees, race with dummies for black non-Hispanic, Hispanic and mixed-race non-Hispanic, age with a cubic, currently enrolled with dummies for full-time master's student, full-time doctoral student, and other student, tenure with a quadratic and region with 8 dummies for census region. Publications include books, journal articles and regional, national or international conference presentations. 
Table 6: Shares of natives and immigrants and means of outcomes by current visa

\begin{tabular}{|lccccc|}
\hline & $\begin{array}{c}(1) \\
\text { Wage } \\
\text { sample } \\
(\%)\end{array}$ & $\begin{array}{c}(2) \\
\text { Hourly } \\
\text { wage }\end{array}$ & $\begin{array}{c}(3) \\
\text { Patent and } \\
\text { publication sample } \\
(\%)\end{array}$ & $\begin{array}{c}(4) \\
\text { Any patent } \\
\text { granted } \\
(\%)\end{array}$ & $\begin{array}{c}\text { More than six } \\
\text { publications } \\
(\%)\end{array}$ \\
\hline U.S. native & 86.3 & 29.6 & 86.4 & 0.009 & 0.036 \\
Born American abroad & 1.2 & 29.3 & 1.1 & 0.013 & 0.042 \\
Born in U.S. territories & 0.3 & 28.1 & 0.3 & 0.006 & 0.031 \\
Naturalized citizen & 7.9 & 31.8 & 7.8 & 0.019 & 0.050 \\
Green card & 3.3 & 29.0 & 3.3 & 0.026 & 0.078 \\
Work & 0.8 & 30.6 & 0.7 & 0.015 & 0.161 \\
Study/training & 0.1 & 17.5 & 0.1 & 0.012 & 0.309 \\
Dependent & 0.0 & 19.7 & 0.1 & 0.004 & 0.010 \\
Other temporary & 0.1 & 21.7 & 0.1 & 0.006 & 0.111 \\
& 100.0 & -- & 100.0 & -- & - \\
\hline Work & 0.3 & 34.3 & 0.3 & 0.016 & 0.098 \\
entry visa was work & 0.4 & 29.0 & 0.3 & 0.018 & 0.250 \\
entry visa was study & 0.1 & 23.5 & 0.1 & 0.005 & 0.069 \\
entry visa was other & 75,940 & & 90,293 & \\
\hline Observations & & & & & \\
\hline
\end{tabular}

Notes: Statistics weighted with survey weights. The wage sample includes those working in the survey reference week. The patent and publication sample includes those who have ever worked. Patents and publications are for the five years prior to the survey week. Publications include published books or journal articles or papers authored for regional, national or international conference presentations. 
Table 7: Selected covariate means by main current visa categories

\begin{tabular}{|lcccccc|}
\hline & $\begin{array}{c}(1) \\
\text { Bachelor's } \\
\text { degree } \\
(\%)\end{array}$ & $\begin{array}{c}(2) \\
\text { Biological } \\
\text { science } \\
(\%)\end{array}$ & $\begin{array}{c}(3) \\
\text { Engineering } \\
(\%)\end{array}$ & $\begin{array}{c}(4) \\
\text { Age }\end{array}$ & $\begin{array}{c}(5) \\
\text { Years } \\
\text { since } \\
\text { migration }\end{array}$ & $\begin{array}{c}\text { If working, } \\
\text { at 4-year } \\
\text { college }(\%)\end{array}$ \\
\hline U.S. native & 65.0 & 4.0 & 5.3 & 44.4 & -- & 5.7 \\
Naturalized citizen & 58.6 & 5.0 & 13.4 & 45.2 & 24.4 & 7.7 \\
Green card & 55.9 & 6.0 & 14.9 & 41.0 & 13.5 & 9.2 \\
Study/training & 28.0 & 13.3 & 17.7 & 31.9 & 6.3 & 78.8 \\
Work & & & & & & \\
$\quad$ entry visa was work & 64.7 & 4.6 & 28.5 & 37.3 & 6.2 & 4.0 \\
$\quad$ entry visa was study & 17.3 & 11.1 & 21.4 & 34.0 & 8.6 & 25.4 \\
Observations & & & 90,293 & & & 75,940 \\
\hline
\end{tabular}

Notes: Means of patent and publication sample (columns 1-5) or wage sample (column 6), weighted with survey weights. The complete set of current visa categories is given in Table 6. 
Table 8: Determinants of log hourly wages: current visa status

\begin{tabular}{|c|c|c|c|c|c|c|c|c|c|c|}
\hline & (1) & (2) & (3) & $(4)$ & (5) & $(6)$ & $(7)$ & $(8)$ & $(9)$ & $(10)$ \\
\hline \multirow[t]{2}{*}{ Naturalized citizen } & 0.071 & -0.040 & 0.071 & 0.001 & -0.029 & -0.040 & -0.014 & -0.052 & -0.041 & 0.026 \\
\hline & $(9.4)$ & $(-5.6)$ & $(9.4)$ & $(0.1)$ & $(-4.0)$ & $(-5.6)$ & $(-1.9)$ & $(-7.3)$ & $(-6.1)$ & $(1.1)$ \\
\hline \multirow[t]{2}{*}{ Green card } & -0.044 & -0.148 & -0.044 & -0.118 & -0.155 & -0.148 & -0.108 & -0.134 & -0.112 & 0.025 \\
\hline & $(-3.8)$ & $(-13.8)$ & $(-3.8)$ & $(-10.5)$ & $(-14.3)$ & $(-13.8)$ & $(-10.3)$ & $(-12.8)$ & $(-11.2)$ & $(0.9)$ \\
\hline Work visa & $\begin{array}{c}0.060 \\
(2.6)\end{array}$ & $\begin{array}{c}-0.069 \\
(-3.3)\end{array}$ & -- & -- & -- & -- & -- & -- & -- & -- \\
\hline \multicolumn{11}{|l|}{ Work visa } \\
\hline entry visa was work & -- & -- & $\begin{array}{c}0.182 \\
(5.2)\end{array}$ & $\begin{array}{c}0.047 \\
(1.4)\end{array}$ & $\begin{array}{c}0.040 \\
(1.2)\end{array}$ & $\begin{array}{c}0.085 \\
(2.6)\end{array}$ & $\begin{array}{c}0.090 \\
(2.9)\end{array}$ & $\begin{array}{c}0.065 \\
(2.1)\end{array}$ & $\begin{array}{c}0.036 \\
(1.2)\end{array}$ & $\begin{array}{c}0.227 \\
(5.9)\end{array}$ \\
\hline entry visa was study & -- & -- & $\begin{array}{c}0.028 \\
(0.5)\end{array}$ & $\begin{array}{l}-0.089 \\
(-2.7)\end{array}$ & $\begin{array}{l}-0.249 \\
(-7.8)\end{array}$ & $\begin{array}{l}-0.151 \\
(-4.8)\end{array}$ & $\begin{array}{l}-0.130 \\
(-4.2)\end{array}$ & $\begin{array}{l}-0.146 \\
(-4.8)\end{array}$ & $\begin{array}{l}-0.132 \\
(-4.5)\end{array}$ & $\begin{array}{l}-0.056 \\
(-1.5)\end{array}$ \\
\hline R-squared & 0.00 & 0.15 & 0.00 & 0.07 & 0.13 & 0.16 & 0.20 & 0.21 & 0.29 & 0.29 \\
\hline Field highest degree & -- & Yes & -- & Yes & Yes & Yes & Yes & Yes & Yes & Yes \\
\hline Highest degree & -- & Yes & -- & -- & Yes & Yes & Yes & Yes & Yes & Yes \\
\hline Age & -- & Yes & -- & -- & -- & Yes & Yes & Yes & Yes & Yes \\
\hline $\begin{array}{l}\text { Sex, race, currently enrolled, } \\
\text { tenure, self-employed }\end{array}$ & -- & -- & -- & --- & -- & -- & Yes & Yes & Yes & Yes \\
\hline Region & -- & -- & -- & -- & -- & -- & -- & Yes & Yes & Yes \\
\hline Occupation, firm size, firm type & -- & -- & -- & -- & -- & -- & -- & -- & Yes & Yes \\
\hline $\begin{array}{l}\text { Age at arrival, U.S. and foreign } \\
\text { experience, U.S. highest degree }\end{array}$ & -- & -- & -- & -- & -- & -- & -- & -- & -- & Yes \\
\hline
\end{tabular}

Notes: Coefficients from OLS regressions using 75,940 observations, weighted with survey weights, with log hourly wage as the dependent variable. Robust t-statistics are reported in parentheses. The omitted category is U.S. native. Each regression also includes dummies for student/trainee visa, dependent of temporary work visa holder, other temporary visa, born American abroad and those born in U.S. territories. Columns 3-9 also include a dummy for work visa with "other" entry visa. Field of highest degree is controlled for with 29 dummies; highest degree with dummies for master's, doctorate and professional degrees; race with dummies for black non-Hispanic, Hispanic and mixed-race non-Hispanic; age with a cubic; currently enrolled with dummies for full-time master's student, full-time doctoral student, and other student; tenure with a quadratic; region with 8 dummies, occupation with 34 dummies; firm size with 7 dummies; firm type with dummies for four-year university, two-year college, business/industry for profit, business/industry self-employed notincorporated, business/industry, non-profit, federal government, state government; age at arrival with a spline with knots every ten years to age 50; receipt of highest degree in U.S. with one dummy; U.S. and foreign experience each with a dummy for any and a linear term. 
Appendix Table 1: Weighted means of covariates entry visa (\% unless specified)

\begin{tabular}{|c|c|c|c|c|c|c|c|}
\hline & \multirow{3}{*}{$\begin{array}{c}\text { (1) } \\
\text { Female }\end{array}$} & \multirow{3}{*}{$\begin{array}{c}\text { (2) } \\
\text { White, } \\
\text { non- } \\
\text { hispanic }\end{array}$} & (3) & (4) & (5) & \multirow{3}{*}{$\begin{array}{c}(6) \\
\text { Tenure } \\
\text { (years) }\end{array}$} & \multirow{3}{*}{$\begin{array}{c}(7) \\
\text { Self- } \\
\text { employed }\end{array}$} \\
\hline & & & \multicolumn{3}{|c|}{ Potential experience } & & \\
\hline & & & $\begin{array}{l}\text { Any } \\
\text { foreign }\end{array}$ & $\begin{array}{c}\text { Foreign } \\
\text { (years) }\end{array}$ & $\begin{array}{c}\text { U.S. } \\
\text { (years) }\end{array}$ & & \\
\hline \multicolumn{8}{|l|}{ A. Immigrant vs native } \\
\hline U.S. native & 50.4 & 88.0 & 0 & 0 & 16.6 & 8.4 & 16.5 \\
\hline Immigrant & 47.0 & 30.9 & 36.4 & 2.8 & 13.1 & 6.7 & 17.7 \\
\hline Born American abroad & 51.6 & 71.4 & 0 & 0 & 13.7 & 6.5 & 14.8 \\
\hline Born U.S. territories & 58.3 & 12.1 & 0 & 0 & 14.2 & 7.1 & 12.8 \\
\hline \multicolumn{8}{|l|}{ B. Entry visa type } \\
\hline Green card & 51.9 & 30.9 & 36.1 & 3.1 & 14.0 & 7.4 & 17.2 \\
\hline Work & 35.2 & 37.7 & 74.9 & 5.6 & 10.5 & 5.8 & 18.0 \\
\hline Dependent & 67.0 & 33.5 & 28.2 & 2.1 & 11.9 & 5.4 & 19.7 \\
\hline Other temporary & 45.6 & 31.1 & 54.7 & 4.4 & 13.4 & 6.5 & 17.7 \\
\hline \multicolumn{8}{|l|}{ Study/training } \\
\hline - for college & 33.4 & 31.9 & 0.9 & 0.1 & 14.0 & 6.5 & 20.2 \\
\hline - for grad school & 32.2 & 18.6 & 0 & 0 & 11.4 & 5.9 & 13.9 \\
\hline - for post-doc & 27.9 & 39.6 & 63.4 & 2.3 & 15.9 & 8.0 & 17.3 \\
\hline - for other & 45.4 & 27.4 & 39.5 & 2.9 & 15.0 & 7.0 & 20.4 \\
\hline Observations & \multicolumn{2}{|c|}{90,293} & & & 75,940 & & \\
\hline
\end{tabular}

Notes: Means of patent and publication sample columns 1-2 and wage sample columns 3-7, weighted with survey weights. Potential experience is measured from the year of receipt of highest degree. Mean years of experience include zeroes. The means of the dummy for any U.S. experience is $0.98-0.99$ for each group. 
Appendix Table 2: Further weighted means of covariates by entry visa

\begin{tabular}{|c|c|c|c|c|c|}
\hline & \multirow{2}{*}{$\begin{array}{c}(1) \\
\text { Currently } \\
\text { Employed } \\
(\%)\end{array}$} & \multirow{2}{*}{$\begin{array}{c}\text { (2) } \\
\text { Currently } \\
\text { employed* } \\
\text { university }\end{array}$} & \multicolumn{3}{|c|}{$\begin{array}{l}(3) \\
\text { Currently enrolled as student }(\%)\end{array}$} \\
\hline & & & $\begin{array}{l}\text { Full time } \\
\text { master's }\end{array}$ & $\begin{array}{l}\text { Full time } \\
\text { doctorate }\end{array}$ & Other \\
\hline \multicolumn{6}{|l|}{ A. Immigrant vs native } \\
\hline U.S. native & 85.5 & 4.8 & 0.9 & 0.4 & 5.1 \\
\hline Immigrant & 86.3 & 8.0 & 1.1 & 1.2 & 6.9 \\
\hline Born American abroad & 88.3 & 5.9 & 1.8 & 0.8 & 5.3 \\
\hline Born U.S. territories & 86.8 & 2.8 & 1.3 & 1.4 & 6.7 \\
\hline \multicolumn{6}{|l|}{ B. Entry visa type } \\
\hline Green card & 85.1 & 4.9 & 1.0 & 4.3 & 7.1 \\
\hline Work & 92.1 & 5.4 & 0.6 & 0.3 & 6.2 \\
\hline Dependent & 81.0 & 7.5 & 1.4 & 1.4 & 7.3 \\
\hline Other temporary & 84.3 & 5.5 & 1.1 & 1.0 & 8.2 \\
\hline \multicolumn{6}{|l|}{ Study/training } \\
\hline - for college & 87.5 & 8.1 & 1.7 & 1.4 & 7.8 \\
\hline - for grad school & 91.1 & 18.8 & 0.8 & 3.5 & 4.1 \\
\hline - for post-doc & 94.5 & 38.2 & 0.1 & 2.0 & 5.4 \\
\hline - for other & 85.3 & 12.0 & 2.3 & 4.7 & 8.6 \\
\hline
\end{tabular}

Note: Means of patent and publication sample, 90,293 observations, weighted with survey weights. University means a four-year post-secondary institution. 
Appendix Table 3: Determinants of log hourly wages: entry visa

\begin{tabular}{|lcccccc|}
\hline & $(1)$ & $(2)$ & $(3)$ & $(4)$ & $(5)$ & $(6)$ \\
\hline Green card & -0.014 & -0.072 & -0.077 & -0.064 & -0.054 & -0.093 \\
Work & $(-1.2)$ & $(-6.2)$ & $(-6.7)$ & $(-5.4)$ & $(-4.7)$ & $(-8.1)$ \\
& 0.164 & 0.046 & 0.035 & 0.035 & 0.055 & 0.026 \\
Dependent & $(8.2)$ & $(2.3)$ & $(1.8)$ & $(1.8)$ & $(2.9)$ & $(1.4)$ \\
& -0.082 & -0.126 & -0.151 & -0.106 & -0.082 & -0.109 \\
Other temporary & $(-3.7)$ & $(-5.9)$ & $(-7.3)$ & $(-5.2)$ & $(-4.1)$ & $(-5.5)$ \\
& -0.138 & -0.198 & -0.218 & -0.223 & -0.193 & -0.221 \\
Study-college & $(-5.9)$ & $(-8.4)$ & $(-9.2)$ & $(-9.3)$ & $(-8.2)$ & $(-9.5)$ \\
& 0.101 & 0.013 & -0.029 & -0.027 & -0.007 & -0.029 \\
Study-graduate & $(4.5)$ & $(0.6)$ & $(-1.3)$ & $(-1.3)$ & $(-0.3)$ & $(-1.3)$ \\
& 0.207 & 0.105 & -0.080 & -0.054 & -0.030 & -0.052 \\
Study-postdoc & $(12.5)$ & $(6.3)$ & $(-4.6)$ & $(-3.3)$ & $(-1.9)$ & $(-3.2)$ \\
& 0.298 & 0.190 & -0.101 & -0.117 & -0.095 & -0.105 \\
Study-other & $(9.9)$ & $(6.4)$ & $(-3.4)$ & $(-4.0)$ & $(-3.4)$ & $(-3.7)$ \\
& -0.016 & -0.078 & -0.072 & -0.059 & -0.033 & -0.061 \\
R-squared & $(-0.5)$ & $(-2.7)$ & $(-2.5)$ & $(-2.1)$ & $(-1.2)$ & $(-2.2)$ \\
\hline Field highest degree & 0.00 & 0.07 & 0.13 & 0.17 & 0.19 & 0.21 \\
Highest degree & -- & Yes & Yes & Yes & Yes & Yes \\
Sex, age, race & -- & -- & Yes & Yes & Yes & Yes \\
Currently enrolled, & -- & -- & -- & Yes & Yes & Yes \\
tenure, self-employed & - & -- & -- & -- & Yes & Yes \\
Region & -- & -- & -- & -- & - & Yes \\
\hline
\end{tabular}

Notes: Coefficients from OLS regressions using 75,940 observations, weighted with survey weights, with log hourly wage as the dependent variable. Robust t-statistics are reported in parentheses. The omitted category is U.S. native. Each regression also includes dummies for Born American abroad and those born in U.S. territories. Field of highest degree is controlled for with 29 dummies, highest degree with dummies for master's, doctorate and professional degrees, race with dummies for black non-Hispanic, Hispanic and mixed-race non-Hispanic, age with a cubic, currently enrolled with dummies for full-time master's student, full-time doctoral student, and other student, tenure with a quadratic and region with 8 dummies for census region. 
Appendix Table 4: Determinants of the probability of being granted a patent: entry visa

\begin{tabular}{|lcccc|}
\hline & $(1)$ & $(2)$ & $(3)$ & $(4)$ \\
\hline Green card & 0.001 & -0.002 & -0.002 & -0.001 \\
Work & $(0.6)$ & $(-3.3)$ & $(-3.1)$ & $(-2.4)$ \\
& 0.022 & 0.002 & 0.001 & 0.000 \\
Dependent & $(8.9)$ & $(2.1)$ & $(0.8)$ & $(0.5)$ \\
& -0.001 & -0.003 & -0.003 & -0.001 \\
Other temporary & $(-0.5)$ & $(-2.2)$ & $(-2.6)$ & $(-1.2)$ \\
Study-college & 0.002 & -0.002 & -0.002 & -0.002 \\
& $(0.6)$ & $-1.6)$ & $(-2.3)$ & $(-2.0)$ \\
Study-graduate & 0.021 & 0.004 & 0.002 & 0.001 \\
& $(6.6)$ & $(2.5)$ & $(1.1)$ & $(1.1)$ \\
Study-post-doc & 0.053 & 0.011 & 0.000 & 0.001 \\
Study-other & $(19.6)$ & $(9.3)$ & $(0.6)$ & $(0.9)$ \\
& 0.066 & 0.025 & 0.003 & 0.001 \\
R-squared & $(13.5)$ & $(9.1)$ & $(2.1)$ & $(1.3)$ \\
Field highest degree & 0.013 & 0.002 & 0.002 & 0.001 \\
Highest degree & $(3.8)$ & $(1.0)$ & $(1.1)$ & $(1.3)$ \\
Sex, age, race & 0.02 & 0.16 & 0.19 & 0.22 \\
\hline
\end{tabular}

Notes: Marginal effects from probit regressions using 90,293 observations, weighted with survey weights, with whether a patent was granted as the dependent variable. T-statistics are reported in parentheses. The omitted category is U.S. native. Each regression also includes dummies for Born American abroad and those born in U.S. territories. Field of highest degree is controlled for with 29 dummies, highest degree with dummies for master's, doctorate and professional degrees, race with dummies for black non-Hispanic, Hispanic and mixed-race non-Hispanic, age with a cubic. 
Appendix Table 5: Determinants of the probability of commercializing or licensing a patent: entry visa

\begin{tabular}{|lcccc|}
\hline & $(1)$ & $(2)$ & $(3)$ & $(4)$ \\
\hline Green card & 0.000 & -0.001 & -0.001 & -0.001 \\
Work & $(0.4)$ & $(-2.7)$ & $(-2.6)$ & $(-1.8)$ \\
& 0.015 & 0.001 & 0.001 & 0.000 \\
Dependent & $(7.6)$ & $(1.6)$ & $(0.8)$ & $(0.8)$ \\
& 0.001 & -0.001 & -0.001 & 0.000 \\
Other temporary & $(0.4)$ & $(-1.0)$ & $(-1.4)$ & $(0.0)$ \\
& 0.002 & -0.001 & -0.001 & -0.001 \\
Study-college & $(0.8)$ & $(-0.9)$ & $(-1.4)$ & $(-1.0)$ \\
& 0.013 & 0.002 & 0.001 & 0.001 \\
Study-graduate & $(5.0)$ & $(1.6)$ & $(0.7)$ & $(0.8)$ \\
& 0.029 & 0.005 & -0.000 & 0.000 \\
Study-post-doc & $(14.5)$ & $(5.9)$ & $(-0.2)$ & $(0.3)$ \\
& 0.032 & 0.012 & 0.001 & 0.001 \\
Study-other & $(8.5)$ & $(5.8)$ & $(1.2)$ & $(0.7)$ \\
& 0.012 & 0.002 & 0.002 & 0.002 \\
R-squared & $(4.0)$ & $(1.6)$ & $(1.7)$ & $(1.9)$ \\
\hline Field highest degree & 0.02 & 0.15 & 0.18 & 0.21 \\
Highest degree & -- & Yes & Yes & Yes \\
Sex, age, race & -- & -- & Yes & Yes \\
\hline
\end{tabular}

Notes: Marginal effects from probit regressions using 90,293 observations, weighted with survey weights, with whether a patent was commercialized or licensed as the dependent variable. T-statistics are reported in parentheses. The omitted category is U.S. native. Each regression also includes dummies for Born American abroad and those born in U.S. territories. Field of highest degree is controlled for with 29 dummies, highest degree with dummies for master's, doctorate and professional degrees, race with dummies for black non-Hispanic, Hispanic and mixed-race nonHispanic, age with a cubic. 
Appendix Table 6: Determinants of probability of publishing or writing papers: entry visa

\begin{tabular}{|lccccc|}
\hline & $(1)$ & $(2)$ & $(3)$ & $(4)$ & $(5)$ \\
\hline Green card & -0.035 & -0.041 & -0.040 & -0.038 & -0.037 \\
Work & $(-6.3)$ & $(-7.3)$ & $(-7.2)$ & $(-6.9)$ & $(-6.7)$ \\
Dependent & 0.039 & 0.022 & 0.003 & -0.002 & -0.001 \\
& $(3.6)$ & $(2.0)$ & $(0.3)$ & $(-0.2)$ & $(-0.1)$ \\
Other temporary & 0.001 & -0.010 & -0.026 & -0.020 & -0.023 \\
& $(0.1)$ & $(-1.0)$ & $(-2.6)$ & $(-2.0)$ & $(-2.3)$ \\
Study-college & -0.018 & -0.027 & -0.037 & -0.038 & -0.040 \\
& $(-1.3)$ & $(-2.1)$ & $(-3.0)$ & $(-3.1)$ & $(-3.5)$ \\
Study-graduate & 0.042 & 0.032 & -0.007 & -0.012 & -0.019 \\
& $(3.5)$ & $(2.8)$ & $(-0.7)$ & $(-1.1)$ & $(-1.8)$ \\
Study-post-doc & 0.272 & 0.231 & 0.018 & 0.014 & 0.005 \\
& $(25.0)$ & $(21.6)$ & $(2.1)$ & $(1.7)$ & $(0.6)$ \\
Study-other & 0.527 & 0.430 & 0.135 & 0.132 & 0.105 \\
& $(25.1)$ & $(20.7)$ & $(7.3)$ & $(7.2)$ & $(6.1)$ \\
R-squared & 0.071 & 0.049 & 0.060 & 0.056 & 0.028 \\
Field highest degree & $(4.5)$ & $(3.1)$ & $(3.7)$ & $(3.5)$ & $(1.8)$ \\
Highest degree & -- & 0.03 & 0.11 & 0.12 & 0.14 \\
Sex, age, race & -- & Yes & Yes & Yes & Yes \\
Currently enrolled, & -- & Yes & Yes & Yes \\
working, working at & -- & -- & -- & Yes & Yes \\
college/ university & & -- & -- & -- & Yes \\
\hline
\end{tabular}

Notes: Marginal effects from probit regressions using 90,293 observations, weighted with survey weights, with whether the individual published a book or a journal article or authored a paper for presentation at a major conference as the dependent variable. T-statistics are reported in parentheses. The omitted category is U.S. native. Each regression also includes dummies for Born American abroad and those born in U.S. territories. Field of highest degree is controlled for with 29 dummies, highest degree with dummies for master's, doctorate and professional degrees, race with dummies for black non-Hispanic, Hispanic and mixed-race non-Hispanic, age with a cubic, currently enrolled with dummies for full-time master's student, full-time doctoral student, and other student. 
Appendix Table 7: Determinants of probability of publishing or writing more than six papers: entry visa

\begin{tabular}{|lccccc|}
\hline & $(1)$ & $(2)$ & $(3)$ & $(4)$ & $(5)$ \\
\hline Green card & -0.008 & -0.010 & -0.008 & -0.007 & -0.006 \\
Work & $(-3.0)$ & $(-3.8)$ & $(-3.5)$ & $(-3.1)$ & $(-2.9)$ \\
& 0.041 & 0.032 & 0.019 & 0.017 & 0.028 \\
Dependent & $(5.8)$ & $(4.9)$ & $(3.3)$ & $(3.0)$ & $(3.3)$ \\
& 0.006 & -0.000 & -0.005 & -0.002 & -0.003 \\
Other temporary & $(1.3)$ & $(-0.1)$ & $(-1.3)$ & $(-0.7)$ & $(-0.9)$ \\
& 0.007 & 0.002 & -0.001 & -0.001 & -0.001 \\
Study-college & $(1.0)$ & $(0.4)$ & $(-0.1)$ & $(-0.3)$ & $(-0.2)$ \\
& 0.025 & 0.020 & 0.000 & -0.000 & -0.003 \\
Study-graduate & $(4.5)$ & $(3.9)$ & $(0.1)$ & $(-0.1)$ & $(-0.8)$ \\
& 0.167 & 0.135 & 0.013 & 0.012 & 0.010 \\
Study-other & $(26.6)$ & $(22.5)$ & $(4.0)$ & $(3.8)$ & $(3.3)$ \\
& 0.042 & 0.027 & 0.035 & 0.034 & 0.029 \\
Study-post-doc & $(5.3)$ & $(3.9)$ & $(5.3)$ & $(5.2)$ & $(3.3)$ \\
& 0.427 & 0.309 & 0.070 & 0.066 & 0.051 \\
R-squared & $(30.1)$ & $(24.6)$ & $(9.6)$ & $(9.1)$ & $(8.2)$ \\
\hline Field highest degree & 0.03 & 0.06 & 0.18 & 0.19 & 0.23 \\
Highest degree & -- & Yes & Yes & Yes & Yes \\
Sex, age, race & -- & -- & Yes & Yes & Yes \\
Currently enrolled, & -- & -- & -- & Yes & Yes \\
working, working at & -- & -- & -- & -- & Yes \\
college/university & & & & & \\
\hline
\end{tabular}

Notes: Marginal effects from probit regressions using 90,293 observations, weighted with survey weights, with whether the sum of the individual's book and journal article publications and papers authored for presentation at a major conference is greater than six as the dependent variable. Tstatistics are reported in parentheses. The omitted category is U.S. native. Each regression also includes dummies for Born American abroad and those born in U.S. territories. Field of highest degree is controlled for with 29 dummies, highest degree with dummies for master's, doctorate and professional degrees, race with dummies for black non-Hispanic, Hispanic and mixed-race nonHispanic, age with a cubic, currently enrolled with dummies for full-time master's student, full-time doctoral student, and other student. 
Appendix Table 8: Determinants of probability of starting a firm with more than 10 employees: entry visa

\begin{tabular}{|lcccc|}
\hline & $(1)$ & $(2)$ & $(3)$ & $(4)$ \\
\hline Green card & -0.0004 & -0.0006 & -0.0006 & -0.0003 \\
Work & $(-0.3)$ & $(-0.5)$ & $(-0.5)$ & $(-0.3)$ \\
& 0.0044 & 0.0035 & 0.0040 & 0.0040 \\
Dependent & $(2.0)$ & $(1.8)$ & $(2.0)$ & $(2.0)$ \\
& 0.0021 & 0.0017 & 0.0020 & 0.0021 \\
Other temporary & $(1.0)$ & $(0.9)$ & $(1.1)$ & $(1.1)$ \\
& -0.0018 & -0.0018 & -0.0016 & -0.0010 \\
Study-college & $-0.8)$ & $(-0.9)$ & $(-0.9)$ & $(-0.5)$ \\
& 0.0053 & 0.0039 & 0.0047 & 0.0051 \\
Study-graduate & $(1.7)$ & $(1.4)$ & $(1.7)$ & $(1.8)$ \\
& 0.0043 & 0.0044 & 0.0116 & 0.0107 \\
Study-post-doc & $(1.7)$ & $(1.8)$ & $(3.5)$ & $(3.4)$ \\
& 0.0017 & 0.0014 & 0.0013 & 0.0035 \\
Study-other & $(0.5)$ & $(0.5)$ & $(0.5)$ & $(1.1)$ \\
& 0.0068 & 0.0061 & 0.0067 & 0.0069 \\
R-squared & $(1.7)$ & $(1.7)$ & $(1.9)$ & $(1.9)$ \\
\hline Field of highest degree & 0.00 & 0.02 & 0.03 & 0.03 \\
Highest degree & -- & Yes & Yes & Yes \\
Sex, age, race & -- & -- & Yes & Yes \\
\hline
\end{tabular}

Notes: Marginal effects from probit regressions using 80,151 observations, weighted with survey weights, with whether a firm with more than ten workers was founded as the dependent variable. Tstatistics are reported in parentheses. The omitted category is U.S. native. Each regression also includes dummies for Born American abroad and those born in U.S. territories. Field of highest degree is controlled for with 28 dummies, highest degree with dummies for master's, doctorate and professional degrees, race with dummies for black non-Hispanic, Hispanic and mixed-race nonHispanic, age with a cubic. 